\title{
L'Adriatico come accesso alla cultura tangibile e intangibile dei porti: il Virtual Museum di Ancona
}

\author{
Paolo Clini \\ Ramona Quattrini \\ Romina Nespeca \\ Renato Angeloni \\ Mirco D'Alessio
}

Abstract

Questo contributo racconta dell'Adriatico come porta di accesso al patrimonio tangibile e intangibile dei porti che vi si affacciano. II lavoro si inserisce nel progetto Interreg IT-HR REMEMBER, che mira a creare una rete per la valorizzazione congiunta di otto porti-città in Italia e Croazia (Ancona, Ravenna, Venezia, Trieste, Fiume, Zara, Spalato, Dubrovnik).

L'obiettivo del lavoro è promuovere il patrimonio culturale marittimo come leva per lo sviluppo sostenibile dei territori: Adrijo è il nuovo network che si propone di far riscoprire i valori legati alla relazione col mare, risorsa capace di generare ricchezza economica, culturale e artistica.

Per la realizzazione di Adrijo è stata sviluppata una piattaforma ICT modulare e multiutente, con un approccio interoperabile e multicanale. I contenuti possono essere visualizzati in diversi modi, rendendo il sistema flessibile e scalabile. All'interno della rete sono ospitate le esperienze digitali (Virtual Museum-VM) personalizzate su ogni realtà locale, ma fruibili a livello globale. In particolare, l'articolo riguarda un approfondimento relativo alVM del porto di Ancona, in corso di sviluppo, descrivendone obiettivi, metodologia e stato di realizzazione.

II connubio fra una scientifica documentazione digitale e un sostenibile sviluppo delle tecnologie di fruizione fa emergere la capacità del disegno di diventare un linguaggio efficace per la promozione dell'immenso patrimonio culturale materiale e immateriale di questi luoghi.

patrimonio culturale tangibile e intangibile, identità culturale, patrimonio culturale digitale, musei virtuali, e-tourism.

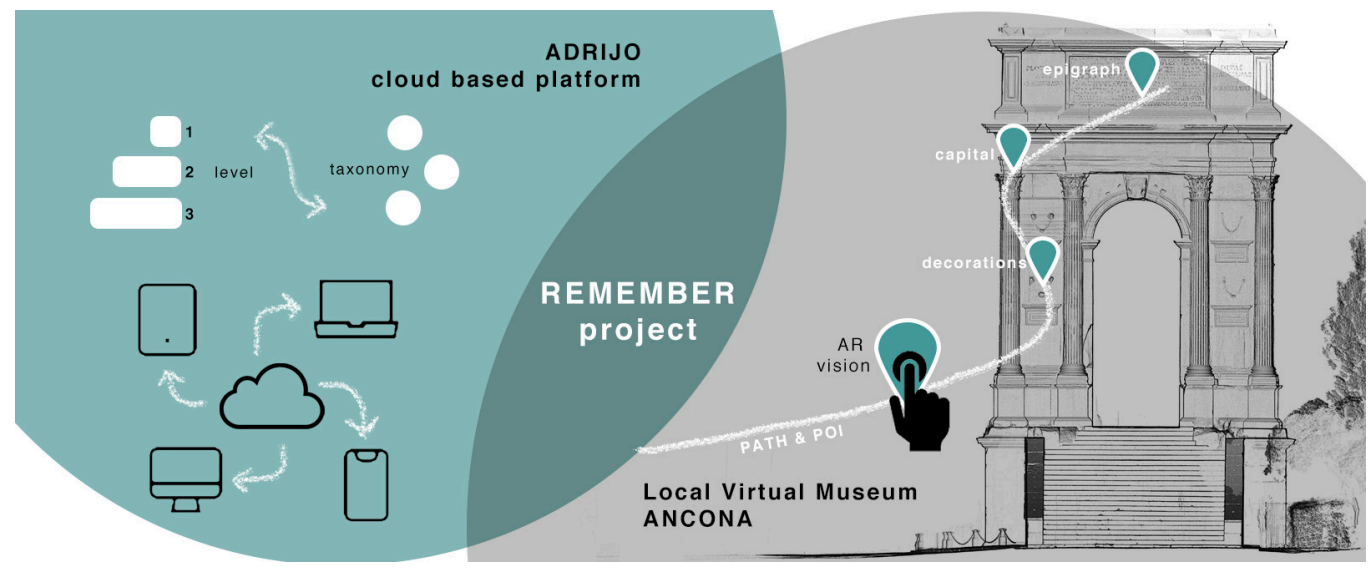




\section{Introduzione}

"II Mediterraneo è il mare della vicinanza, l'adriatico è il mare dell'intimità" [Matvejević 1999]. Iniziamo con questa citazione leggendaria il racconto di un lavoro che mira consapevolmente alla definizione di una nuova identità adriatica condivisa, attraverso la valorizzazione del suo patrimonio culturale tangibile e intangibile.

La storia dell'Adriatico è una storia millenaria, complessa e difficile, che si interroga sulla nozione contemporanea di 'comunità adriatica' dove ciò che unisce è molto più di ciò che divide. Mare stretto e in buona parte chiuso, l'Adriatico è un microcosmo fisico e culturale del Mediterraneo, come scrive Pierre Cabanes [Cabanes 200 I]. Lo stesso palcoscenico dove si animano i tredici racconti di Storie di Adriatico [Anselmi 1996], questa volta al plurale. Un intreccio di umanità che vuole narrare quello che la storiografia non riesce a esprimere, facendo vacillare quel senso di identità dei luoghi per arrivare forse a riaffermarlo con più vigore. II progetto Interreg REMEMBER (REstoring the MEmory of Adriatic ports sites. Maritime culture to foster Balanced tErritorial growth), che qui presentiamo, si sviluppa attorno all'idea che le tradizioni, le storie e le professioni dei porti sono la leva per lo sviluppo sostenibile futuro dei territori.

Una città portuale, come Ancona, contiene un infinito patrimonio di cultura, saperi e storia in quello che è il luogo più simbolico e identitario della città: il porto. Un contenitore di azioni e conoscenze con uno sguardo diretto al futuro e all'innovazione, che diviene il traino dello sviluppo dell'intera città. Un luogo che dalla storia antica a quella contemporanea, ha ospitato le più importanti svolte. Anche il cinema ne ha dato omaggio, grazie a registi come Visconti e Monicelli: il porto di Ancona è quello dove Carlo Giuffrè insegue Monica Vitti nel film La ragazza con la pistola, ed è il motivo per cui oggi, a lei è stata dedicata un'opera di street art nel muraglione della Lanterna Rossa (fig. I).

Fig. I. A sinistra una scena tratta dal film La ragazza con la pistola girata nella Lanterna Rossa del porto di Ancona e a destra una foto di com'è ogri quel. luogo, dedicato al film

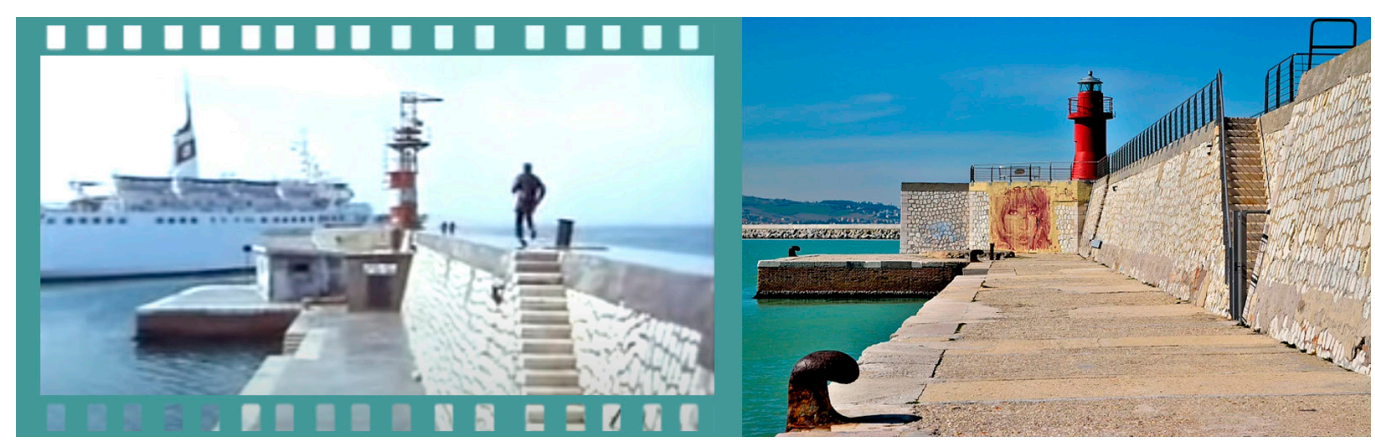

La conservazione è un passo obbligatorio per la promozione, e azioni come quelle messe in atto nel progetto REMEMBER sono una forma di proiezione dello stato attuale verso direzioni di sviluppo future [ICOM $20 \mathrm{II}$ ]. In particolare, il patrimonio culturale immateriale porto-marittimo viene continuamente ricreato dalla comunità. Puntare su questo aspetto significa recuperare e migliorare il rapporto tra porto e città, collegando il presente al passato. Questa doppia visione stabilisce le origini dell'identità delle città portuali e la loro ricchezza in termini di cultura, opere, produzioni, investimenti e pone il sistema portuale al centro dello sviluppo della comunità locale.

A questo scopo, il progetto costruisce un network fra le città che si basa sullo sviluppo di una piattaforma cloud-based per la valorizzazione dei patrimoni marittimi, sfruttando una collaborazione attiva tra i partner italiani e croati. Un altro aspetto chiave del progetto REMEMBER è costituito dalla digitalizzazione del patrimonio culturale sia tangibile sia immateriale, al fine di garantire un'enorme e significativa raccolta di dati per lo sfruttamento e la conservazione dellidentità dei porti. In questo modo, si vuole aumentare l'attrattiva delle economie locali utilizzando le ICT nella digitalizzazione dei contenuti culturali, coltivando 
le offerte turistiche per ridurre la stagionalità turistica e creare nuovi e qualificati posti di lavoro che colleghino competenze digitali e culturali.

La piattaforma realizzata combina la parola italiana Adriatico con la parola croata Jadransko, generando ADRIJO (fig. 2). Questo nuovo marchio costituisce il risultato di un processo cognitivo e creativo, frutto di una costruzione linguistica che unisce, per mezzo del linguaggio, le due sponde.Adrijo è la rete dei porti di 8 città marinare:Ancona, Ravenna,Venezia,Trieste, Fiume, Zara, Spalato, Dubrovnik. I Porti-Città coinvolti nel progetto REMEMBER condividono un patrimonio culturale porto-marittimo millenario, un background comune e un senso di appartenenza derivante dalle intense relazioni commerciali e sociali.

Oltre alla piattaforma, si realizzeranno otto Local Virtual Museums (VMs) combinando l'esperienza tradizionale del concetto museale con i vantaggi offerti dalle ICT [Antinucci 2007, pp. 79-86; Djindjian 2007, pp. 9- I4; Clini et al. 20 I7, pp. 20 I-227; Pugliese 20 I 8]. I VMs hanno l'obiettivo di far fruire il patrimonio marittimo e portuale come "esperienza immersiva remota", superando la mancanza di tempo o risorse per viaggiare, la mancanza di spazio espositivo, offrendo un facile trasferimento di conoscenze comuni a siti remoti e lo sfruttamento circolare del patrimonio comune.

II know-how della nostra unità di ricerca, fondato sulla conoscenza e la padronanza degli strumenti del disegno e della rappresentazione [Clini, Quattrini 2020, I 5 I - I75], costituisce le fondamenta per lo sviluppo della rete e delle esperienze digitali locali.

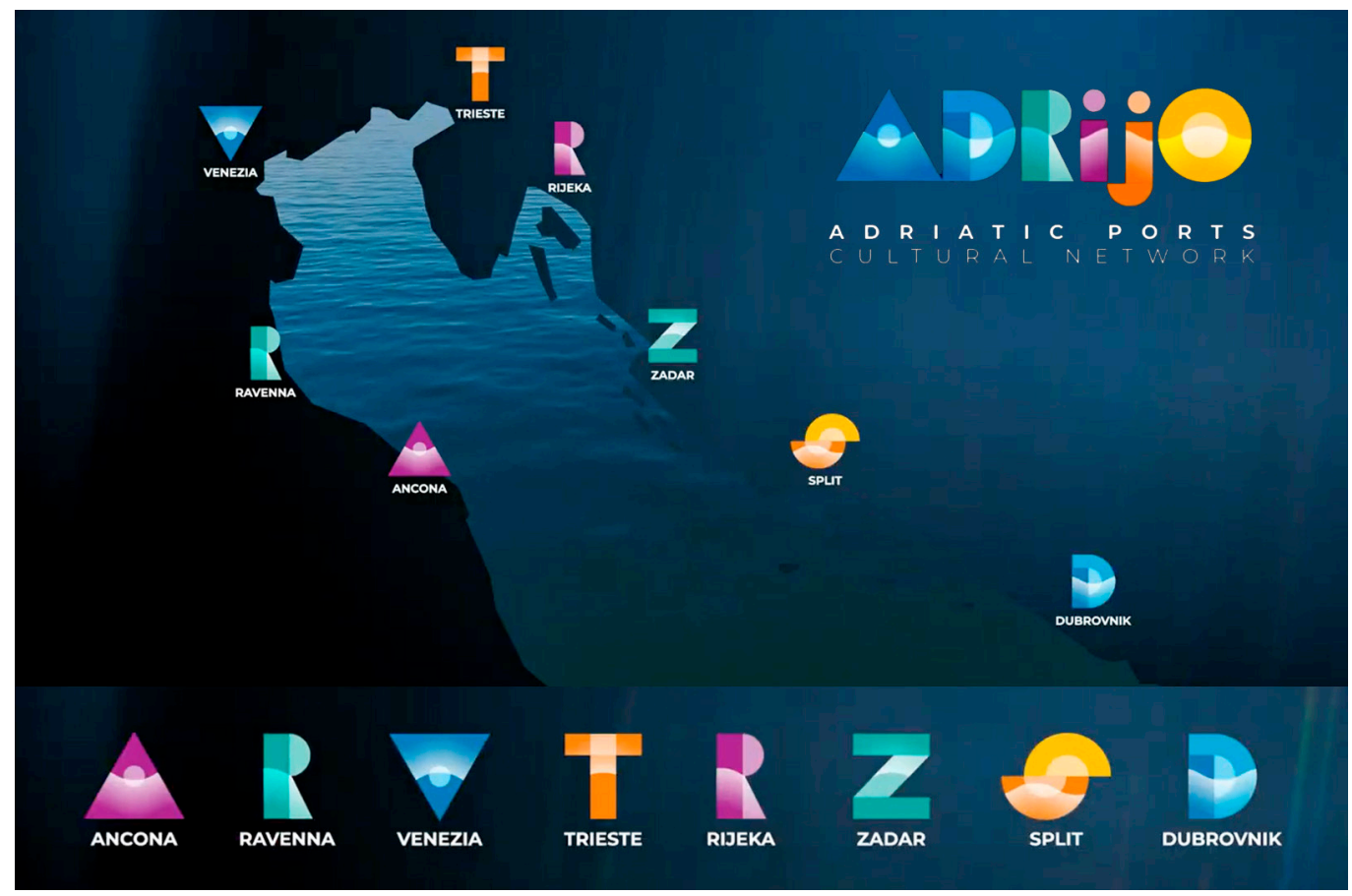

\section{Obiettivi e metodologia}

Come anticipato, il progetto REMEMBER mira a sfruttare appieno le potenzialità di valorizzazione culturale, sociale ed economica del patrimonio tangibile e intangibile dei porti.

Questo progetto di cooperazione internazionale ha, tra i suoi obiettivi, quello di raccogliere e rappresentare le diversità e i minimi comun denominatori delle identità culturali che ne fanno parte, offrendo un modello adattabile e scalabile su altre diverse realtà comunitarie simili. Così come in [Mollica, Marraffa 2020, pp. 3553-3576] REMEMBER vuole raccontare luoghi che pur nella loro unicità vogliono interconnettersi per incrementare il proprio valore intrinseco che insieme supera la sola somma delle singole unità. 
Fig. 3. La struttura tassonomica di riferimento per la classificazione del patrimonio marittimo Tangibile e Intangibile nel progetto REMEMBER. Tre categorie e le relative sottocategorie.
La metodologia applicata vede lo sviluppo di alcuni nodi fondamentali:

- l'analisi del patrimonio culturale a disposizione, attuale e potenziale, sia esso materiale sia immateriale;

- la messa a punto di nuovi linguaggi digitali e nuovi media comunicativi, o l'applicazione consapevole e ottimizzata di codici digitali ormai assodati, per ampliare e rendere sostenibile la domanda turistica;

- l'applicazione di ogni forma comunicativa che miri all'accessibilità dei documenti digitali prodotti o, meglio, che miri alla produzione di documenti digitali progettati e realizzati già accessibili anche a utenti con disabilità.

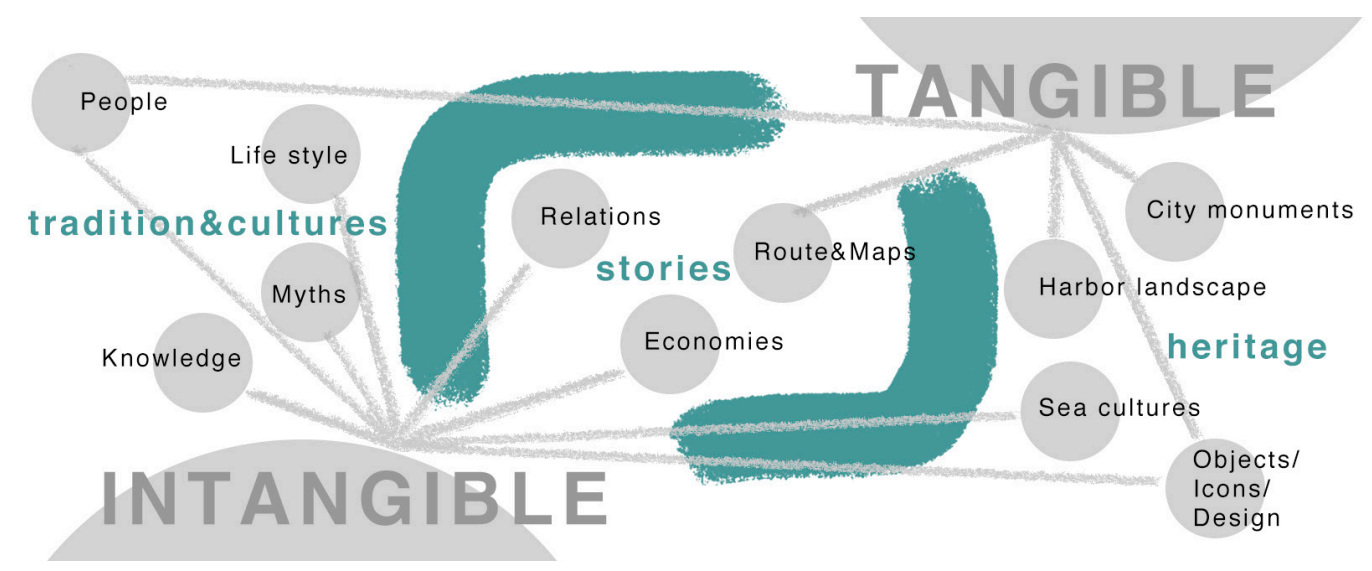

\section{Il patrimonio culturale marittimo tangibile e intangibile}

Negli ultimi decenni del $X X$ secolo il termine 'patrimonio' è stato caratterizzato da espansione e trasferimento semantico, determinando una generalizzazione dell'uso di questa parola. Da un approccio puramente normativo, si è passati a un approccio meno restrittivo, basato sulla capacità dell'oggetto di suscitare alcuni valori che hanno portato la società in questione a considerarlo come tale.

Il patrimonio culturale non si ferma ai monumenti e alle collezioni di oggetti. Comprende anche tradizioni o espressioni viventi ereditate dai nostri antenati e trasmesse ai nostri discendenti, come tradizioni orali, arti dello spettacolo, pratiche sociali, rituali, eventi festivi, conoscenze e pratiche riguardanti la natura e l'universo o le conoscenze e le abilità per produrre artigianato tradizionale [UNESCO 2003]. Questo sviluppo ha permesso anche di riconoscere il patrimonio culturale immateriale, a lungo ignorato, come patrimonio da tutelare e salvaguardare [Smith, Akagawa 2008, Vecco 20 I0, pp. 321-324, Kirshenblatt-Gimblett 20 I 4, pp. I 63- I74, Rodzi et al. 20 I 3, Higginbottom 2020, pp. 58 I I-58 I4].

Alcuni lavori mostrano come la narrazione del patrimonio immateriale passa attraverso le principali sfere elaborative della conoscenza, sostenute dai linguaggi del disegno e della rappresentazione. II patrimonio intangibile e i suoi luoghi di manifestazione si intrecciano in un percorso di esplorazione che porta al perpetuarsi di riti e tradizioni, incuriosendo e attirando sempre di più i flussi turistici [Salucci, Petrillo 2020, pp. 3774-3799].

Per promuovere correttamente tutto il patrimonio, sia esso tangibile sia intangibile, è necessario mettere in campo una filiera digitale consapevole e sostenibile che si basa su una digitalizzazione scientifica, su nuove forme di interazione virtuale, sulla misurazione del gradimento dei pubblici e, ultima ma fondamentale, sulla formazione di nuove competenze [Clini, Quattrini 2020, pp. 151-175]. É ormai noto come le tecnologie inneschino nuovi linguaggi comunicativi che trasformano i processi alla base dell'apprendimento e i livelli di attenzione [Empler et al. 2020, pp. 3293-33 I2]. Ma occorre sempre tener presente che gli strumenti 
digitali hanno dimostrato di essere un processo abilitante, uno stimolo per avviare processi di condivisione e opportunità, non una soluzione [Niccolucci 2007].

Con queste premesse, consapevoli dell'immenso valore del patrimonio marittimo in loro possesso, i partner del progetto REMEMBER si sono da subito mossi allo studio e alla ricerca analitica dei punti di forza delle proprie unicità e delle relazioni territoriali reciproche.

Questo primo lavoro di indagine ha portato a una fase collettiva di confronto che ha generato una struttura tassonomica di supporto, una griglia concettuale dove andare a collocare le singole identità locali. I capisaldi degli storytelling progettati sono tre macrocategorie: Traditions\&cultures ( I), Stories (2) e Heritage (3). All'interno di queste si sviluppano alcune specifiche sottocategorie che connotano con maggiore dettaglio l'ambito di trattazione: People, Knowledge, Myths, Life style ( I); Relations, Route\&Maps, Economies (2); City monuments, Harbor landscape, Sea cultures, Objects/lcons/Design (3) (fig. 3).

Ciascun partner, secondo il piano editoriale e lo storytelling del proprio Virtual Museum, ha realizzato nove contenuti comuni (3 per ogni categoria), da incasellare nella struttura tassonomica condivisa che costituirà la base della piattaforma comune. Ogni scheda racconta del tangibile e dell'intangibile del porto tramite narrazioni multimediali in grado di far immergere i visitatori nel luogo con occhi diversi.

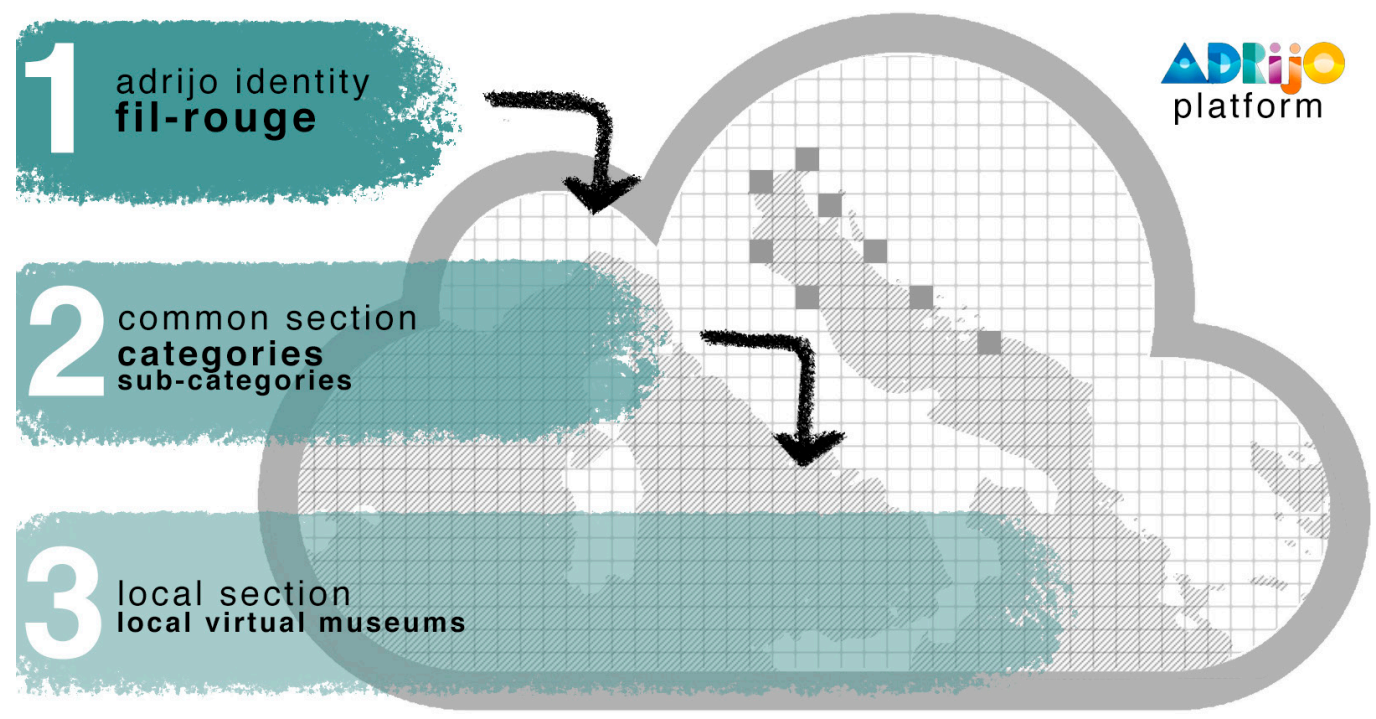

\section{La piattaforma ADRIJO}

"Una volta digitalizzato, il materiale culturale è una risorsa preziosa per i creatori e le imprese, che possono riutilizzarlo per sviluppare prodotti e servizi innovativi" [European Commission $201 \mathrm{I}]$.

Secondo questa ipotesi, l'architettura della piattaforma comune ADRIJO è stata sviluppata seguendo il paradigma dei servizi basati sul cloud, con l'obiettivo di creare una struttura open-data a lungo termine e collegata ai repository correlati al Cultural Heritage. Questo approccio consente l'interoperabilità tra diverse piattaforme (in loco, online, mobile) e tra diversi utenti (usabilità aumentata dei metadati sia per esperti che per non esperti). II sistema ICT è in grado di trasmettere informazioni su diverse scale, fornendo agli utenti contenuti aggiornati; allo stesso tempo, gli amministratori possono monitorare costantemente le sue prestazioni, essendo in grado di dedurre informazioni utili sulle esigenze, le abitudini e le preferenze dei turisti [Clini et al. 2020].

La struttura si compone di tre livelli: un primo livello introduttivo che traccia il fil rouge del progetto, la rete identitaria adriatica marittima raccontata da un testimonial scelto ad hoc; un secondo livello comune che raccoglie e narra i contenuti dei singoli partner declinati 
sulla tassonomia condivisa, in modo da permettere una lettura trasversale delle unicità locali tramite le relazioni reciproche; e, infine, un terzo livello, che rimanda a un approfondimento verticale sui singoli Virtual Museum locali, fisici o solo virtuali (fig. 4).

La piattaforma Adrijo permette quindi la navigazione dei contenuti tramite parole chiave e tramite un'interfaccia di navigazione geografica, particolarmente interessante soprattutto se si vuole accedere attivando la modalità AR, quando si è fisicamente all'interno delle aree portuali dei partner di progetto. Le schede e i contenuti multimediali a esse collegati (gallerie, audio, video, modelli 3D, tour e immagini sferiche) sono automaticamente collocati nello spazio circostante sfruttando le informazioni di georeferenziazione del dispositivo mobile che si sta utilizzando (fig. 5). La narrazione sfrutta semplici e assodate pratiche digitali di comunicazione e ne sperimenta altre nuove, sulle quali saranno effettuati test di usabilità, appena messe a sistema.

Fig. 5. Esempio di visualizzazione in modalità $A R$ de contenuti esplorabili nell piattaforma ADRIJO de progetto REMEMBER. Simulazione al porto di Zadar.

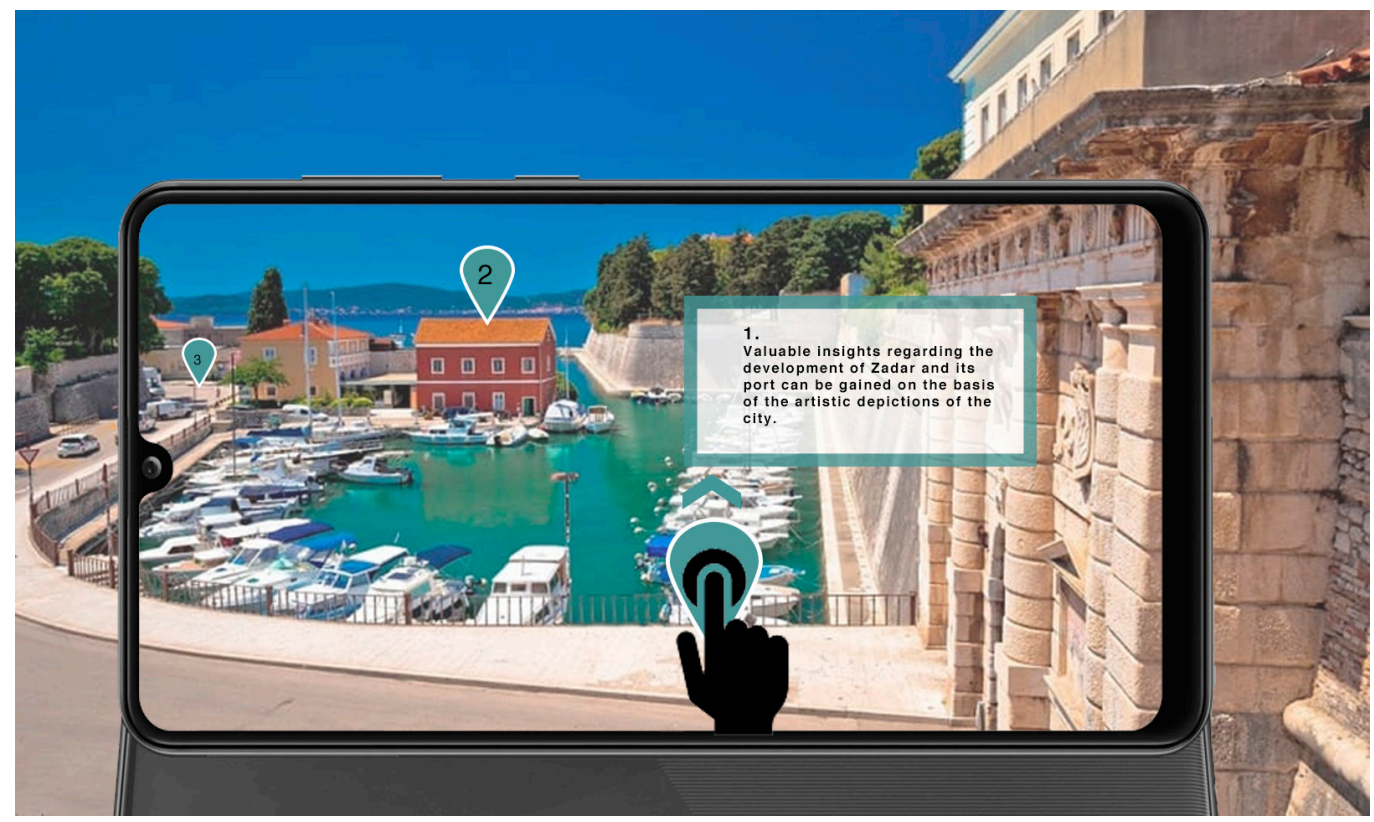

\section{Local Virtual Museum del porto di Ancona}

La partnership proposta e gli esperti tecnici coinvolti, già attivi in molti progetti sul Digital Cultural Heritage, hanno avviato un flusso di lavoro in grado di sviluppare contenuti di alta qualità ed esperienze virtuali che fanno riferimento a solide linee guida per musei virtuali [Pescarin 2014, pp. I31-140]. L'utilizzo delle tecnologie digitali svolge un ruolo essenziale nella creazione di prodotti e installazioni altamente evocativi e coinvolgenti, che consentono ai visitatori di conoscere il patrimonio culturale e i siti attraverso esperienze più stimolanti. Tuttavia, la progettazione di tecnologie digitali richiede una visione strategica che consenta di collocare l'elemento tecnologico in un piano coerente di comunicazione dell'identità, partendo da una chiara individuazione degli obiettivi.

II Virtual Museum del porto di Ancona ha per obiettivo quello di accompagnare il visitatore alla scoperta dei molteplici aspetti della vita dello scalo, sfruttando il paradosso di infrastruttura in movimento: una realtà di strutture imponenti, statiche, che tuttavia si adatta al mutare delle esigenze, delle tecnologie e dei traffici, in movimento con la contemporaneità.

Il porto infatti ospita servizi avanzati, come la logistica, i cantieri navali come manifatture che coniugano l'estro artigianale con la più avanzata tecnologia, attività tradizionali come la pesca, e il traffico passeggeri - vocazione del porto di Ancona e veicolo non solo di persone, ma anche di culture, contaminazioni culturali, idee. Ulteriore filone che interseca il racconto 
Fig. 6. Immagine sferica in visualizzazione little planet delle maggiori aree interessate dal Local Virtual Museum del porto di Ancona. del porto è la consapevolezza del patrimonio monumentale e storico-artistico di rilievo, testimonianze lasciate da oltre 2000 anni di attività portuali nello stesso sito in una costante sovrascrittura.

Sull'integrazione tra acqua e terra, tradizioni e trasformazione, dialogo e confronto con la comunità locale circostante si colloca la narrazione del museo virtuale del porto di Ancona (fig. 6). Per assolvere a questa missione saranno usati diversi linguaggi, tenendo conto anche della dimensione internazionale dell'utenza e della necessità di veicolare messaggi facilmente assimilabili: immagini, suoni e parole concorrono alla descrizione di una rete di punti di interesse - $\mathrm{POI}$ - fruibili da smartphone o altri supporti digitali per rendere immediatamente disponibile questo racconto tra passato e futuro.

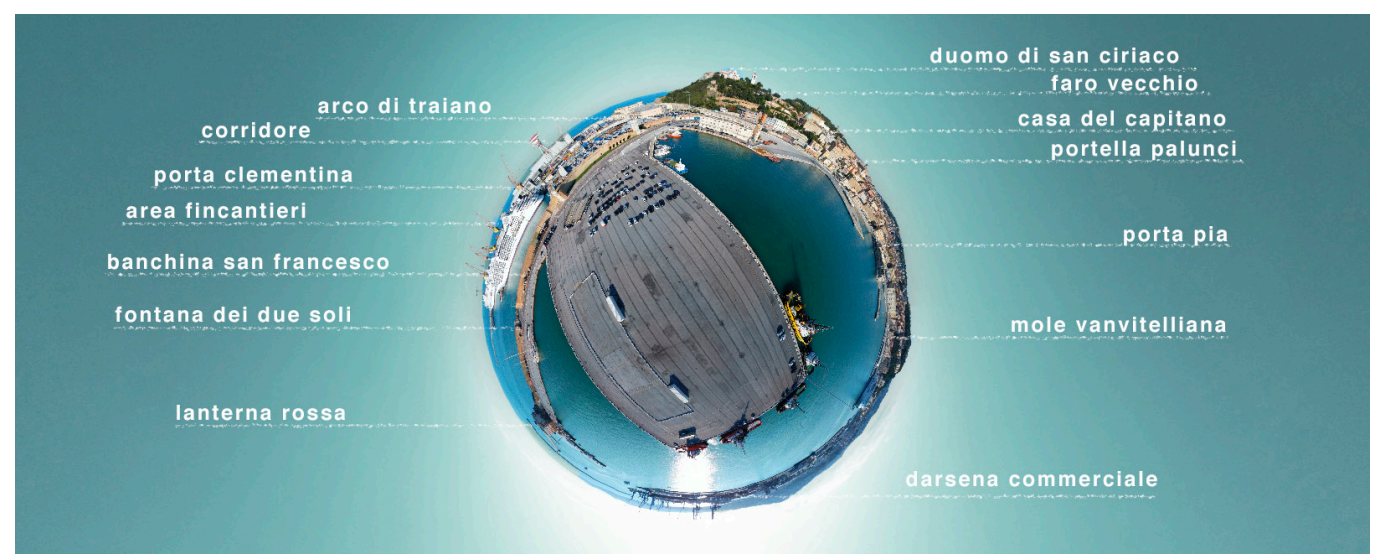

In particolare, il percorso si snoda attraverso I0 POI, dislocati lungo $3 \mathrm{~km}$ di fascia portuale, un tratto denso di luoghi di vita, fra i più simbolici di questo ecosistema: dalla Lanterna Rossa al mercato ittico del Mandracchio (fig. 7).

Al fine di sviluppare nuove forme di interazione si è ideata una forma ibrida di visualizzazione dei contenuti geolocalizzati, creata ad hoc per alcuni POI del percorso, fondendo il tracciamento basato su AR Vision già presente nella piattaforma comune ADRIJO con una visualizzazione AR sull'oggetto fisico reale. Inizialmente, appena l'utente inquadra la segnale-

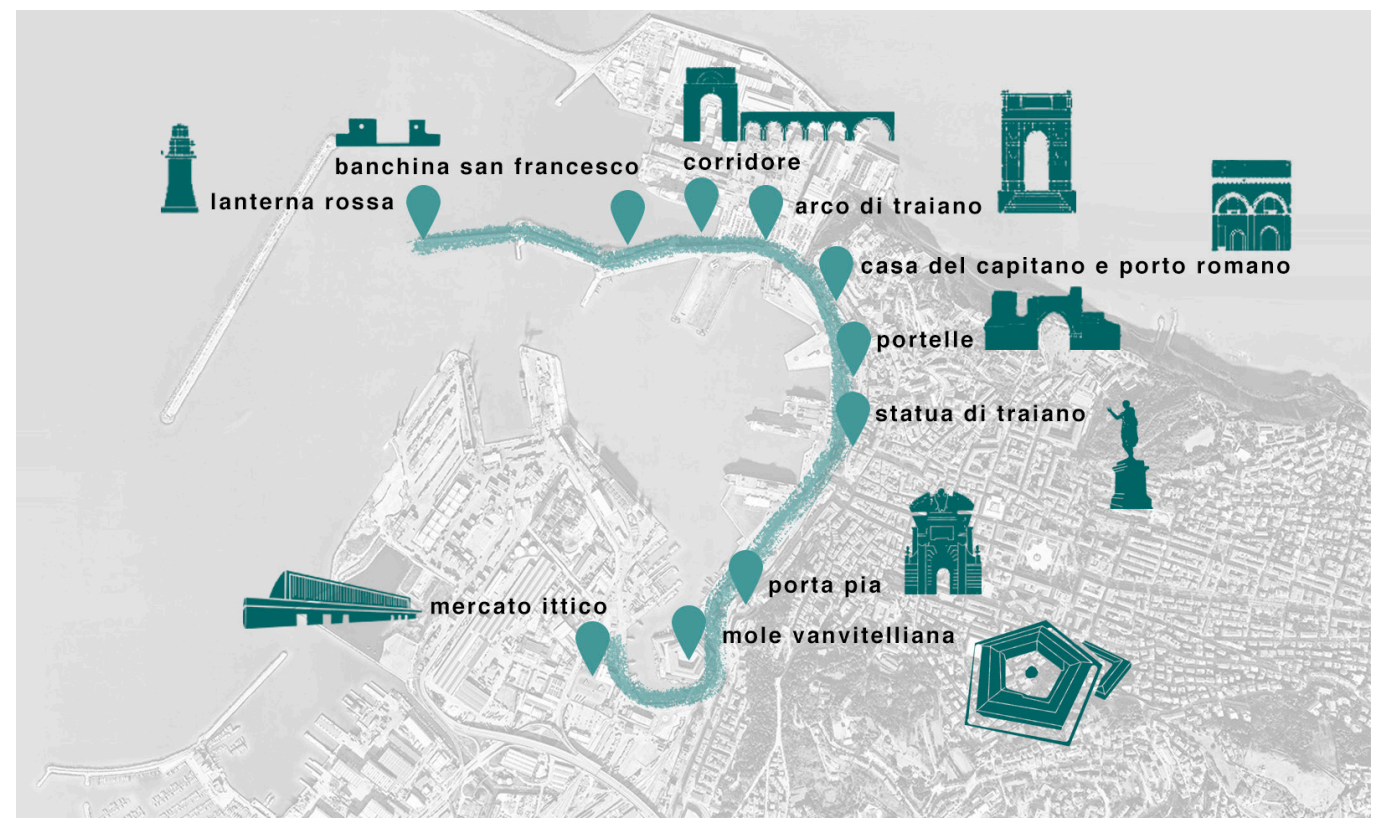

Fig. 7. Il percorso del Local Virtual Museum di Ancona, con la localizzazione dei dieci Point Of Interest di approfondimento. 
tica, identificativa del progetto e appositamente studiata come Wayfinding, si attiva la riproduzione automatica di un video introduttivo al POI. Quindi, il dispositivo tiene traccia delle informazioni di georeferenziazione, rilevando e riconoscendo le caratteristiche geometriche nell'ambiente reale per stabilire corrispondenze di coordinate di immagini 3D e 2D. Questa parte del lavoro è ancora in via sviluppo e la sua efficacia verrà validata con test di usabilità. A fianco del racconto più emozionante ed evocativo di immagini, suoni e video del reale, si possono esplorare contenuti digitali 3D virtuali realizzati secondo un approccio scientifico di documentazione digitale. Le numerose campagne di acquisizione multitemporali e multiscala costituisco un database molto cospicuo da cui sono stati elaborati i disegni digitali degli oggetti più significativi: in particolare, la Porta Clementina e l'Arco di Traiano sono i POI più popolati di contenuti virtuali tridimensionali (figg. 8, 9). La metodologia utilizzata integra strumenti e tecniche di rilevamento 3D, secondo le procedure standard già assodate di documentazione digitale del patrimonio materiale (topografia, laser scanner, fotogrammetria da drone e fotogrammetria terrestre).

Fig. 8. Alcune viste prospettiche della nuvola VM di Ancona, in scala di grigi. di punti del percorso de

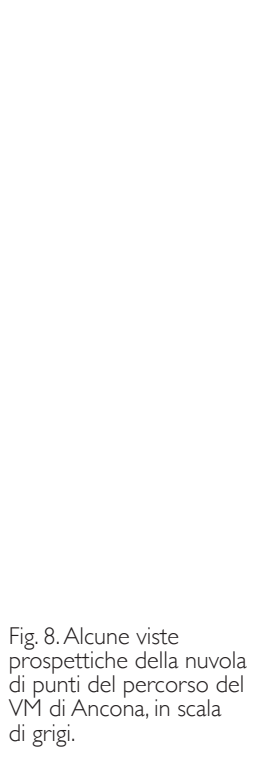

Conclusioni e sviluppi futuri

La pandemia ha mostrato la fragilità del nostro patrimonio culturale, ma soprattutto dei nostri sistemi museali, spesso disarmati di fronte all'emergenza. La necessità di un accesso digitale al patrimonio si è affermata con forza e tutti gli operatori dell'Umanesimo digitale devono inevitabilmente lavorare in questa direzione.

II progetto REMEMBER opera consapevolmente su questa strada: la piattaforma ADRIJO garantisce l'accesso remoto al patrimonio marittimo di una rete di otto porto-città italiane e croate che affermano attorno all'Adriatico la propria identità culturale e sociale. Uno dei risultati raggiunti è la democratizzazione dell'accesso al nostro patrimonio al fine di sostenere la diversità, l'inclusività, la creatività e l'impegno critico nell'istruzione e nella condivisione delle conoscenze.

Inoltre, è obbligatorio costituire reti permanenti in cui le istituzioni pubbliche cooperino e coinvolgano il settore privato nella digitalizzazione del materiale culturale, al fine di aumentare l'accessibilità online del patrimonio culturale europeo e stimolare la crescita nelle industrie creative europee [European Union 2018]. Uno dei risultati di REMEMBER è la cross-fertilizzazione tra diverse istituzioni pubbliche al fine di consentire il trasferimento tecnologico nel dominio dei beni culturali digitali. Le autorità portuali, infatti, fungono da attori per valorizzare e promuovere gli elementi culturali portuali, nonché per garantire la conser- 
Fig. 9. Approfondimento tridimensionale sull'Arco diTraiano, uno dei POI del Local Virtual Museum del porto di Ancona. Nuvola di punti, modello mesh, modello texturizzato e ortoimmagine in scala di grigi. vazione del patrimonio culturale marittimo tangibile e immateriale. La partnership REMEMBER è impegnata a stimolare capacità di innovazione, promuovendo l'uso della tecnologia e delle competenze digitali e migliorando il ruolo delle istituzioni culturali nel raccontare le nostre storie europee. Per garantire tale obiettivo la partnership di progetto, costituita per la maggior parte da autorità portuali, si affianca alle istituzioni museali e si serve degli operatori del Digital Cultural Heritage, che tramite la tecnologia al servizio del disegno e della rappresentazione cuciono su misura nuovi linguaggi e nuovi media comunicativi.

Si conferma come in altri casi, che l'accesso al patrimonio materiale e immateriale di questi luoghi è il risultato di un processo di sviluppo e cooperazione che trova nel ruolo del disegno il fulcro di sviluppo e gestione.

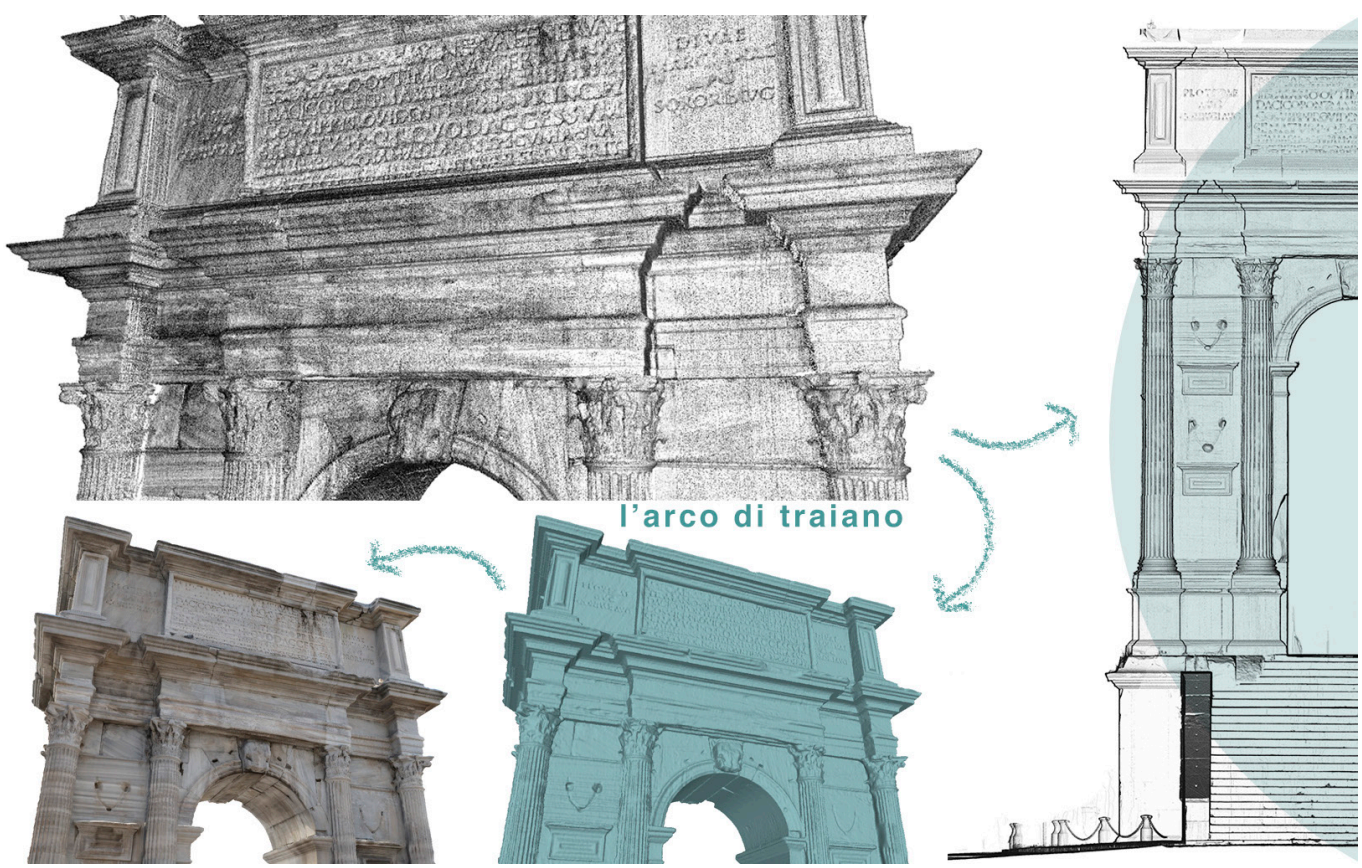

Ringraziamenti

II progetto qui presentato è finanziato nell'ambito del programma Interreg IT-HR 2019-202 I, APPLICATION ID I004274 I. || contenuto di questo documento riflette solo il punto di vista dell'autore e le autorità di programma non sono responsabili per qualsiasi uso che possa essere fatto delle informazioni in esso contenute. Si ringraziano Gianluca Gagliardini, Luigi Sagone e Floriano Capponi per la collaborazione nelle fasi di acquisizione.

\section{Riferimenti bibliografici}

Anselmi S. (1996). Storie di Adriatico. Bologna: II Mulino.

Antinucci F. (2007). The virtual museum. In Archeologia e calcolatori. Supplement, pp. 79-86.

Cabanes P. (200 I). Storie dell'Adriatico. Paris: Édition du Seuil.

Clini P. et al. (2017). Real/Not Real: Pseudo-Holography and Augmented Reality Applications for Cultural Heritage. In A. Ippoliti, M. Cigola (eds.). Handbook of Research on Emerging Technologies for Digital Preservation and Information Modeling. Chapter 9. Publisher: IGI Global, pp. 201-227.

Clini P. et al. (2020). ICT driven platform for high-quality virtual contents creation and sharing with e-Tourism purposes. The interreg IT-HR REMEMBER project. In CEUR Workshop Proceedings, vol. I, pp. 2687-269I.

Clini P., Quattrini R. (2020). Umanesimo digitale e bene comune? Linee guida e riflessioni per una salvezza possibile/Digital humanities and Commons: guidelines and recflections for a possible salvation. In Capitale Culturale. Studies on (I I), pp. I 5 I - I 75 .

Djindjian F. (2007). The virtual museum: an introduction. In Archeologia e Calcolatori. Supplement, pp. 9- I4.

Empler T., Caldarone A., Fusinetti A. (2020). Musei tra narrazione, visualità e new media. In A. Arena et al. (a cura di). Connettere. Un disegno per annodare e tessere. $42^{\circ}$ Convegno internazionale dei Docenti delle Discipline della Rappresentazione. Milano: FrancoAngeli, pp. 3293-3312. 
European Commission (20II). COMMISSION RECOMMENDATION of 27 October $201 \mathrm{I}$ on the digitisation and online accessibility of cultural material and digital preservation (201 I/7I I/EU). In Official Journal of the European Union, pp. 39-43.

European Union (2018). Digital solutions in the field of cultural heritage. A Policy Brief from the Policy Learning Platform environment and resource efficiency.

Higginbottom G. (2020). Intangible Cultural Heritage. In Encyclopedia of Global Archaeology. Cham: Springer International Publishing, pp. 58||-58|4

ICOM (20I I). Museums and Sustainable Development: How can ICOM Support, in Concrete Terms, the Museum Communities Sustainable Development Projects?" In Proceedings of the Advisory Committee Meeting. Paris, France, 6-8 June 201 : <http:// archives.icom.museum/download/june20 I I/panels/I 10602_\%20JM_ panel I.pdf> (consultato il 28 maggio 202 I).

Kirshenblatt-Gimblett B. (20 I 4). Intangible Heritage as Metacultural Production. In Museum International 66 ( I-4), pp. I63- I 74. <https://www.tandfonline.com/doi/abs/ I 0.1 I I I/muse. I 2070> (consultato il 28 maggio 202 I).

Matvejević P. (1999). Mediterranean: A Cultural Landscape. Berkeley: University of California Press.

Mollica S., Marraffa A. (2020). La riconnessione delle città costiere. La rete dei fari italiani. In A. Arena (a cura di). Connettere. Un disegno per annodare e tessere. $42^{\circ}$ Convegno internazionale dei Docenti delle Discipline della Rappresentazione. Milano: FrancoAngeli, pp. 3553-3576.

Niccolucci F. (2007). Virtual museums and archaeology: an international perspective. In Archeologia e Calcolatori, Supplemento I, pp. 15-30.

Pescarin S. (2014). Museums and Virtual Museums in Europe: Reaching expectations. In SCIRES-IT-SClentific RESearch and Information Technology, 4 (I) pp. |3|-|40.

Pugliese A. (20 I8). Musei, le esperienze digitali che conquistano il visitatore (e quelle che no). In Network Digital 360. <https:// www.agendadigitale.eu/cultura-digitale/musei-le-esperienze-digitali-che-conquistano-il-visitatore-e-quelle-che-no/> (consultato il 28 maggio 2021).

Rodzi N.I.M., Zaki S.A., Subli S.M.H.S. (20I3). Between Tourism and Intangible Cultural Heritage. In Procedia - Social and Behavioral Sciences, vol. 85, pp. 4 II-420.

Salucci A., Petrillo D. (2020). Connessioni tra terra e cielo. Forma e immagine nel racconto delle qualità intangibili di uno spazio urbano. In A. Arena et al. (a cura di). Connettere. Un disegno per annodare e tessere. $42^{\circ}$ Convegno internazionale dei Docenti delle Discipline della Rappresentazione. Milano: FrancoAngeli, pp. 3774-3799.

Smith L., Akagawa N. (2008). Intangible Heritage. L. Smith \& N. Akagawa (eds.). London: Routledge.

UNESCO (2003). Convention for the safeguarding of the intangible cultural heritage.

Vecco M. (20I0). A definition of cultural heritage: From the tangible to the intangible. In Journal of Cultural Heritage, II (3), pp.32 I-324:<http://orcp.hustoj.com/wp-content/uploads/20 16/0 I/20 I 0-A-definition-of-cultural-heritage_From-the-tangible-to-the-intangible.pdf> (consultato il 28 maggio 202I).

\section{Autori}

Paolo Clini, Università Politecnica delle Marche, p.clini@univpm.it

Ramona Quattrini, Università Politecnica delle Marche, r.quattrini@univpm.it

Romina Nespeca, Università Politecnica delle Marche, r.nespeca@univpm.it

Renato Angeloni, Università Politecnica delle Marche, r.angeloni@univpm.it

Mirco D'Alessio, Università Politecnica delle Marche, m.dalessio@pm.univpm.it

Per citare questo capitolo: Clini Paolo, Quattrini Ramona, Nespeca Romina, Angeloni Renato, D'Alessio Mirco (202I). L'Adriatico come accesso alla cultura tangibile e intangibile dei porti: il Virtual Museum di Ancona/Adriatic Sea as an access to the tangible and intangible culture of ports: the Ancona Virtual Museum. In Arena A., Arena M., Mediati D., Raffa P. (a cura di). Connettere. Un disegno per annodare e tessere. Linguaggi Distanze Tecnologie.Atti del $42^{\circ}$ Convegno Internazionale dei Docenti delle Discipline della Rappresentazione/Connecting. Drawing for weaving relationship. Languages Distances Technologies. Proceedings of the $42^{\text {th }}$ International Conference of Representation Disciplines Teachers. Milano: FrancoAngeli, pp. $528-547$. 


\title{
Adriatic Sea as an Access to the Tangible and Intangible Culture of Ports: the Ancona Virtual Museum
}

\author{
Paolo Clini \\ Ramona Quattrini \\ Romina Nespeca \\ Renato Angeloni \\ Mirco D'Alessio
}

Abstract

This paper tells of the Adriatic Sea as a gateway to the tangible and intangible heritage of the ports that overlook it. The work is part of the Interreg IT-HR REMEMBER project, which aims to create a network for the joint enhancement of 8 city ports in Italy and Croatia (Ancona, Ravenna, Venice, Trieste, River, Zadar, Split, Dubrovnik).

The aim is to promote maritime cultural heritage as a lever for the sustainable development of the territories: Adrijo is the new network that aims to rediscover the values linked to the relationship with the sea, a resource capable of generating economic, cultural and artistic wealth.

For the realization of Adrijo, a modular and multi-user ICT platform has been developed, with an interoperable and multi-channel approach. Content can be displayed in several ways, making the system flexible and scalable. The network hosts digital experiences (Virtual Museum-VM) custommade to every local reality, but usable globally. In particular, the paper concerns an in-depth study related to the VM of the port of Ancona, under development, describing its objectives, methodology and state of implementation.

The merge of scientific digital documentation and a sustainable development of fruition technologies reveals the ability of drawing to become an effective language for the promotion of the immense material and immaterial Cultural Heritage of these places.

Keywords

tangible and intangible cultural heritage, cultural identity, digital cultural heritage, virtual museums, e-tourism.

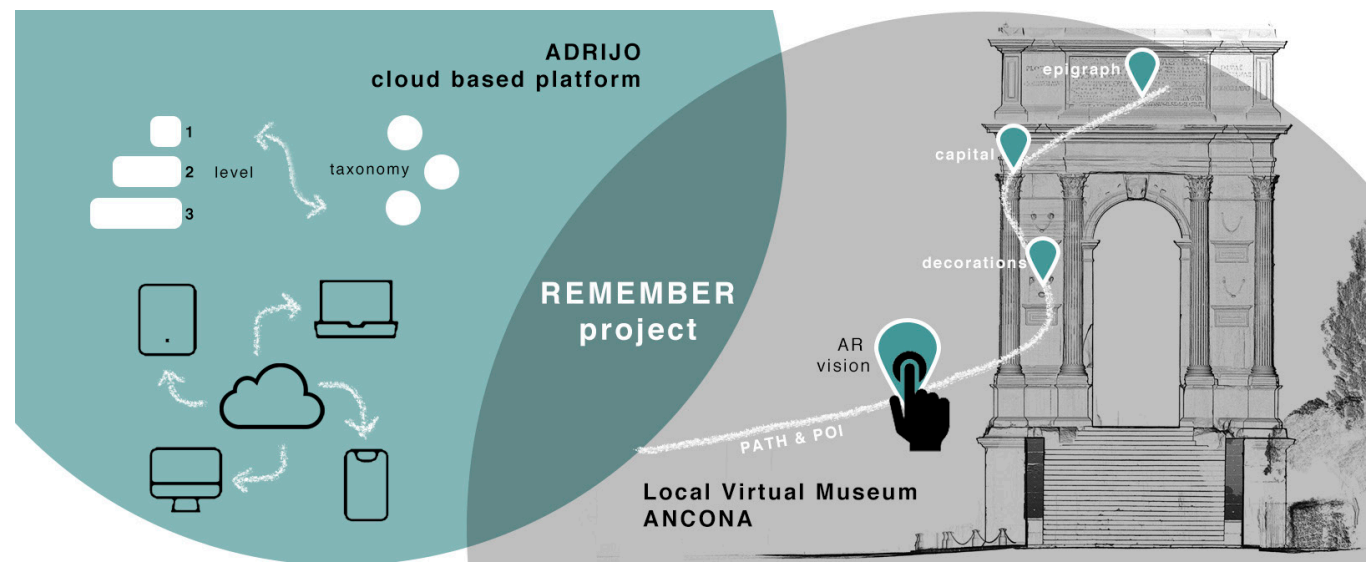




\section{Introduction}

"The Mediterranean is the sea of proximity, the Adriatic is the sea of intimacy" [Matvejević 1999]. Let's start with this legendary quote the presentation of a work that consciously aims at defining a new shared Adriatic identity, through the enhancement of its Tangible and Intangible Cultural Heritage.

The history of the Adriatic is a thousand-year history, complex and difficult, which questions the contemporary notion of 'Adriatic community' where what unites is much more than what divides. Narrow and largely closed sea, the Adriatic is a physical and cultural microcosm of the Mediterranean, as Pierre Cabanes [Cabanes 200 I] The same stage where the thirteen tales of Stories of the Adriatic [Anselmi 1996] come alive, this time in the plural.An interweaving of humanity that wants to narrate what historiography fails to express, faltering that sense of identity of the places, perhaps to reaffirm it with more life.

The INTERREG REMEMBER project (REstoring the MEmory of Adriatic ports sites. Maritime culture to foster Balanced tErritorial growth), which we present here, develops around the idea that the traditions, stories and professions of ports are the lever for the future sustainable development of the territories.

A port city, like Ancona, contains an inestimable Cultural Heritage $(\mathrm{CH})$, knowledge and history, in what is the most symbolic and identity place of the city: the port. A container of actions and knowledge with a direct look at the future and innovation, which becomes the driving force behind the development of the entire community. A place that from ancient to contemporary history, has hosted the most important turns. Cinema has also paid tribute to it, thanks to directors such as Visconti and Monicelli. The port of Ancona is the one where Carlo Giuffrè pursues Monica Vitti in the film La ragazza con la pistola, the reason why today, a work of street art has been dedicated to her in the wall of the Red Lantern (fig. I).

Fig. I. On the left a scene from the film La ragazza con la pistola shot in the Red Lantern of the port Of Ancona and on the right a photo of what that place is like today, dedicated to the protagonist

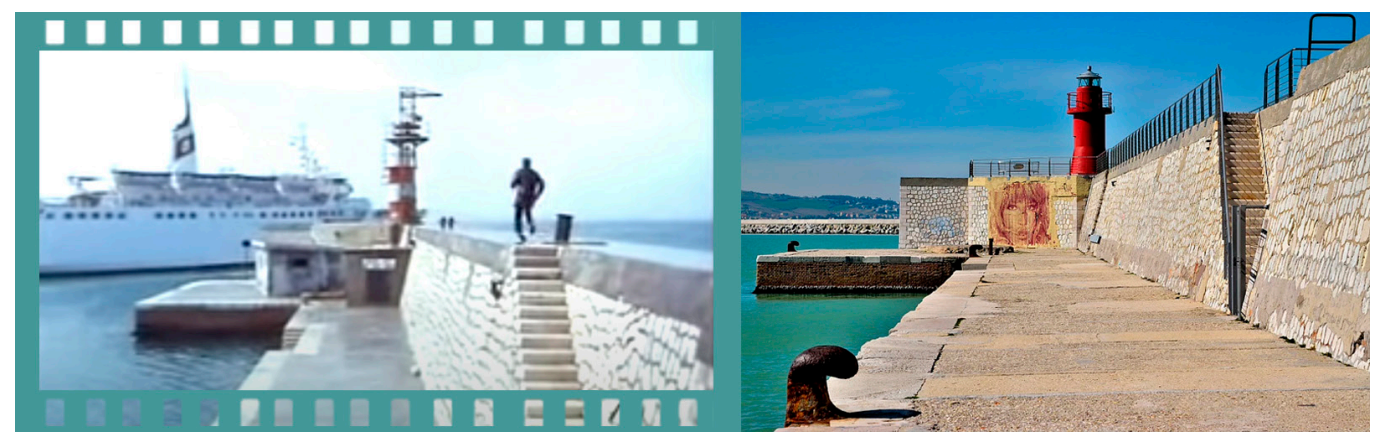

Conservation is a mandatory step for promotion, and actions such as those implemented in the REMEMBER project are a form of projection of the current state towards future development directions [ICOM 20I I] In particular, the community is continually recreating the intangible $\mathrm{CH}$ of the seaport. Focusing on this aspect means recovering and improving the relationship between port and city, linking the present to the past. This dual vision establishes the origins of the identity of port cities and their richness in terms of culture, works, productions, investments and it places the port system at the center of the development of the local community.

For this reason, the project builds a network between cities built on the development of a cloud-based platform for the enhancement of maritime assets, exploiting an active collaboration between the Italian and Croatian partners. Another key aspect of the REMEMBER project is the digitization of both tangible and intangible cultural heritage, in order to ensure a huge and significant collection of data for the exploitation and preservation of the identity of ports. In this way, the aim is to increase the attractiveness of local economies by using ICT 
in the digitization of cultural content, enriching the tourist offers to reduce the seasonality of tourism and create new and qualified jobs that connect digital and cultural skills.

The platform created combines the Italian word Adriatic with the Croatian word Jadransko, generating ADRIJO (fig. 2). This new brand is the result of a cognitive and creative process, the result of a linguistic construction that unites, through language, the two sides. Adrijo is the network of ports of 8 maritime cities:Ancona, Ravenna,Venice, Trieste, Fiume, Zara, Split, Dubrovnik. The Ports-Cities involved in the REMEMBER project share a thousand-year-old port-sea cultural heritage, a common background and a sense of belonging deriving from the intense commercial and social relationships.

In addition to the platform, 8 Local Virtual Museums (VMs) will be realized by combining the traditional experience of the museum concept with the advantages offered by ICT [Antinucci 2007, pp. 79-86; Clini et al. 2017, pp. 201-227; Pugliese 20 I8].VMs aim to make the maritime and port heritage a "remote immersive experience", overcoming the lack of time or resources to travel, the lack of exhibition space, offering an easy transfer of common knowledge to remote sites and the circular exploitation of the common heritage.

The know-how of our research unit, based on knowledge and manage of the tools of drawing and representation field [Clini, Quattrini 2020, pp. I5I-175] constitutes the basis for the development of the network and local digital experiences.

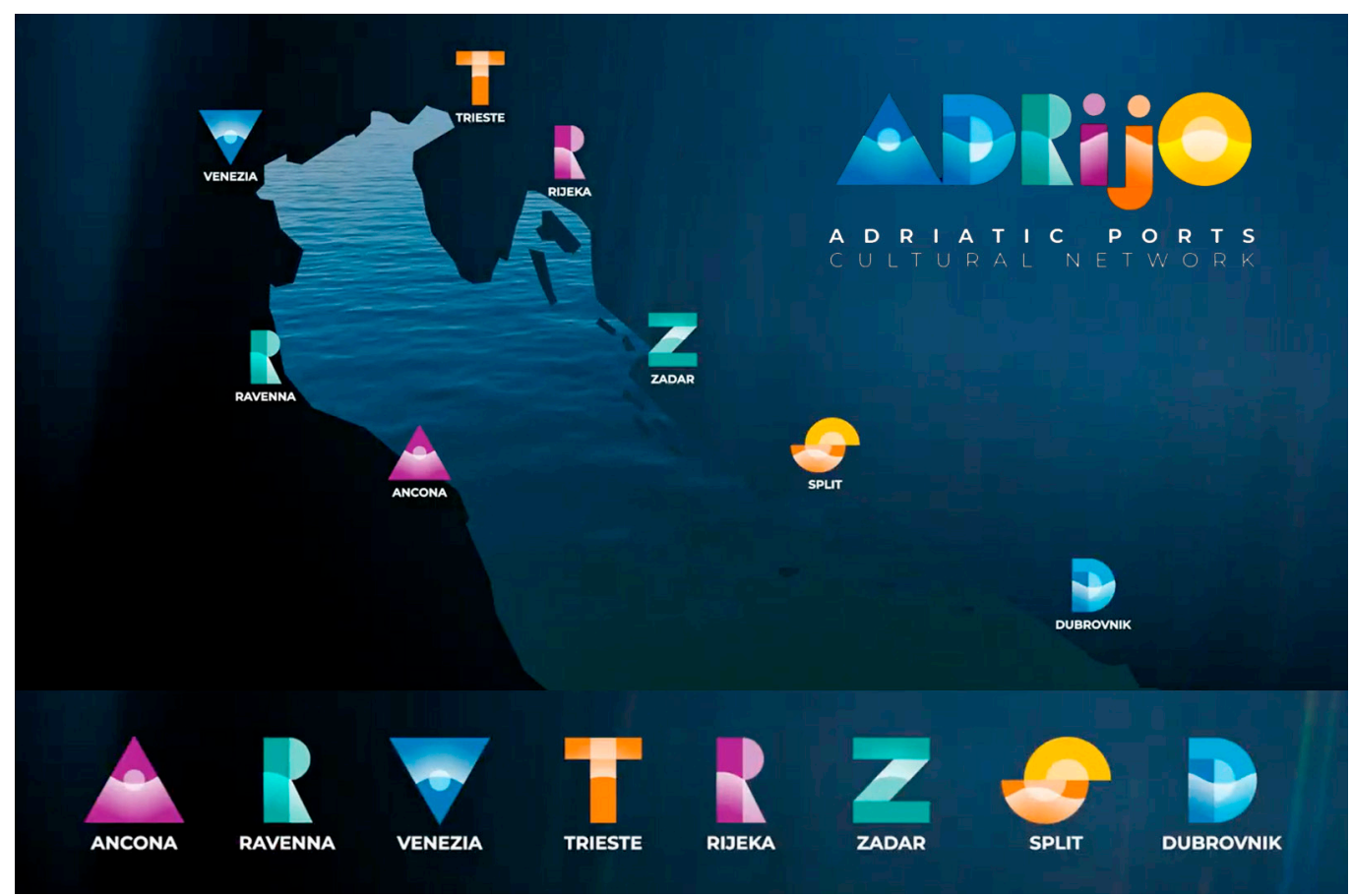

\section{Objectives and Methodology}

As anticipated, the REMEMBER project aims to fully exploit the potential of cultural, social and economic enhancement for the Tangible and Intangible Heritage of seaports.

One of its goals is to collect and represent the diversity and lowest common denominators of the cultural identities of the partnership, offering an adaptable and scalable model on other similar Community realities. As in [Mollica, Marraffa 2020], REMEMBER wants to narrate places that even uniqueness wants to create interconnections to increase their intrinsic value that combined exceeds the sum of the individual units alone. 
The methodology applied concerns the development of some key points:

- the analysis of the available cultural heritage, current and potential, both material and immaterial;

- the development of new digital languages and new communication media, or the conscious and optimized application of digital codes now established, to expand and make sustainable tourist demand;

- the application of all forms of communication that are designed to make the digital documents produced accessible or, better enough, that are designed to produce digital documents designed and produced that are already accessible to users with disabilities.

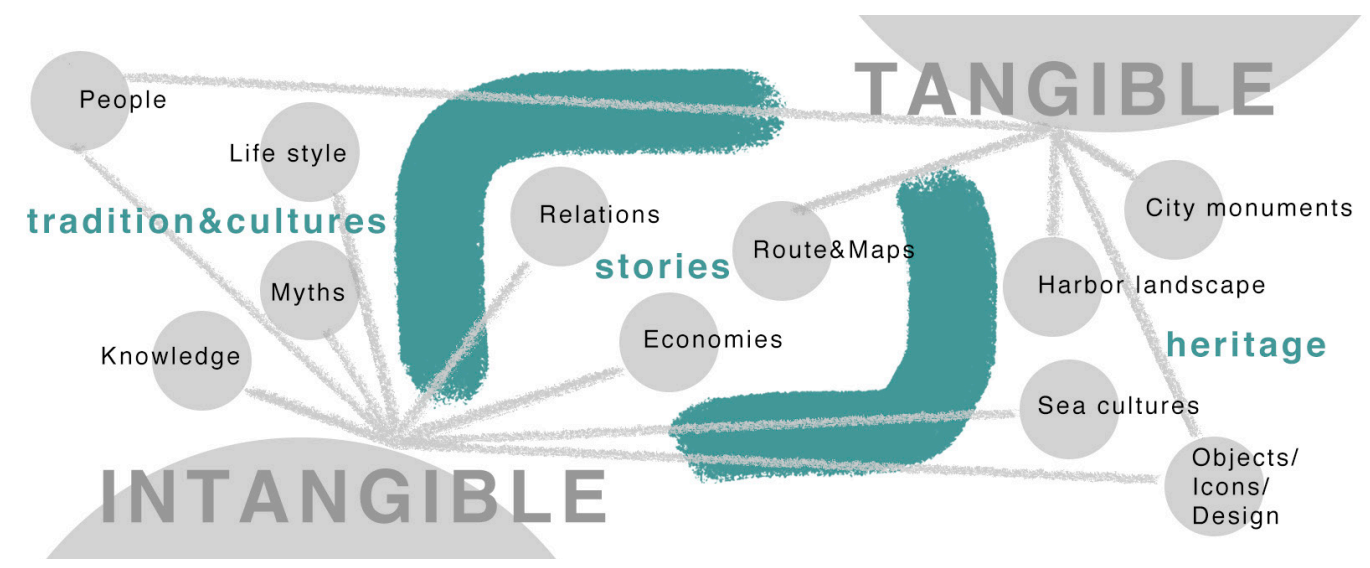

\section{Tangible and intangible maritime cultural heritage}

In the last decades of the 20th century, the term 'heritage' was characterized by expansion and semantic transfer, leading to a generalization of the use of this word. From a purely normative approach, we have moved on to a less restrictive approach, based on the ability of the object to arouse certain values that have led the company in question to consider it as such.

Cultural heritage does not stop at monuments and collections of objects. It also includes living traditions or expressions inherited from our ancestors and passed on to our descendants, such as oral traditions, performing arts, social practices, rituals, festive events, knowledge and practices regarding nature and the universe or the knowledge and skills to produce traditional crafts [UNESCO 2003] This development has also made it possible to recognize the intangible cultural heritage, which has long been ignored, as a heritage to be protected and safeguarded [Smith, Akagawa 2008; Vecco 2010, pp. 321-324; Kirshenblatt-Gimblett 20 I4; pp. I63- 174; Rodzi et al. 20 I 3; Higginbottom 2020, pp. 58 I I-58 I 4].

Some works show how the tale of intangible heritage passes through the main elaborative spheres of knowledge, supported by the languages of drawing and representation. The intangible heritage and its places of manifestation are intertwined in a path of exploration that leads to the perpetuity of rites and traditions, intrigued and attracting more and more tourist flows [Salucci, Petrillo 2020, pp. 3774-3799].

To properly promote all the heritage, both tangible and intangible, it is necessary to implement a conscious and sustainable digital supply chain that is based on scientific digitalization, on new forms of virtual interaction, on measuring the satisfaction of the public and, last but fundamental, on the training of new skills [Clini, Quattrini 2020, pp. I5 I- I 75]. It is now known how technologies trigger new communication languages that transform the processes underlying learning and attention levels [Empler et al. 2020, pp. 3293-33/2]. But it must always be borne in mind that digital tools have proven to be an enabling process, a stimulus to start processes of sharing and opportunities, not a solution [Niccolucci 2007]. 
With these premises, aware of the big value of their maritime heritage, the partners of the REMEMBER project immediately moved to study and analytical research the strengths of their uniqueness and mutual territorial relations.

This first analysis work led to a collective phase of comparison that generated a supportive taxonomic structure, a conceptual grid where to go to place individual local identities. The cornerstones of the designed storytelling are three macros-categories: Traditions\&cultures (I), Stories (2) and Heritage (3). Within these are developed some specific subcategories that connote in more detail the scope of treatment: People, Knowledge, Myths, Life style (I); Relations, Route\&Maps, Economies (2); City monuments, Harbor landscape, Sea cultures, Objects/lcons/Design (3) (fig. 3).

Each partner, according to the editorial plan and storytelling of its Virtual Museum, has created 9 common contents ( 3 for each category), to be included in the shared taxonomic structure that will form the basis of the common platform. Each card tells of the tangible and intangible of the port through multimedia narratives able to immerse visitors in the place with different eyes.

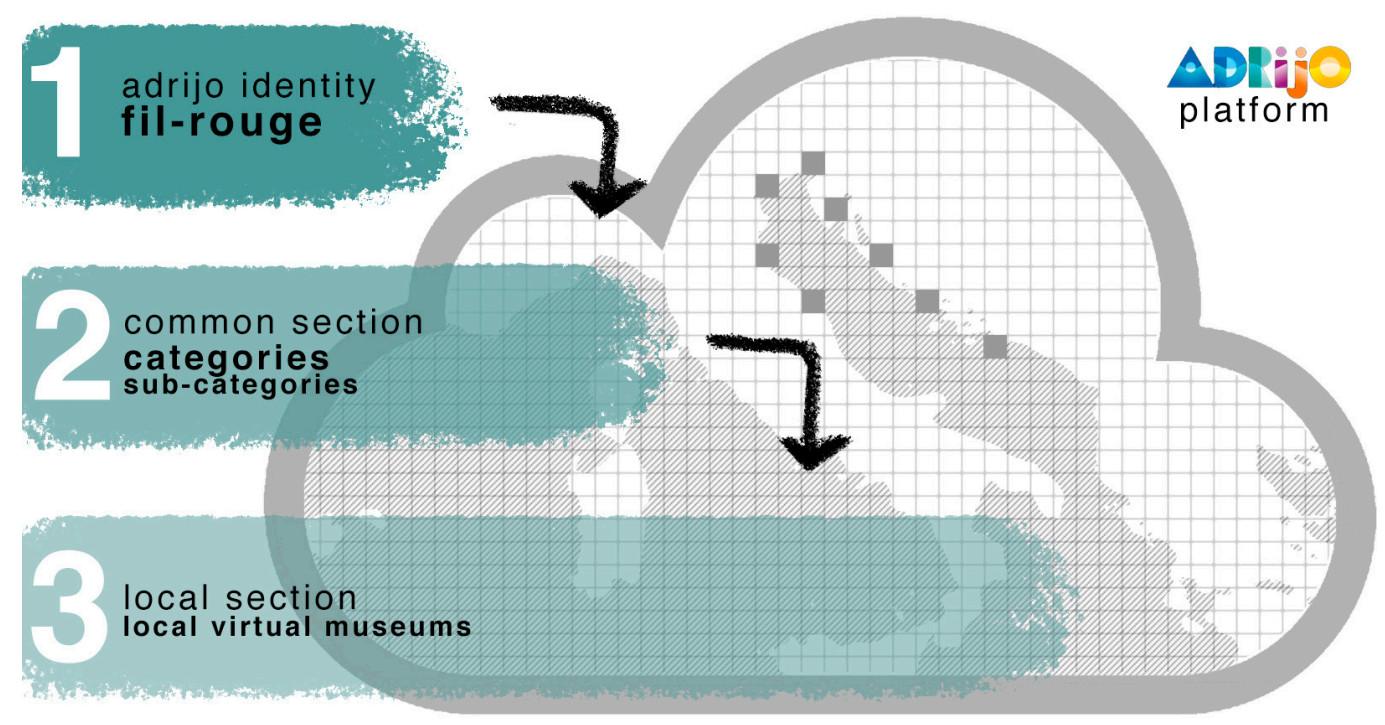

\subsection{The ADRIJO Platform}

"Once digitized, cultural material is a valuable resource for creators and businesses, who can reuse it to develop innovative products and services" [European Commission $20 \mathrm{II}$ ]. According to this hypothesis, the architecture of the ADRIJO common platform was developed following the paradigm of cloud-based services, with the aim of creating a long-term open-data structure linked to cultural heritage-related repositories. This approach allows interoperability between different platforms (on-site, online and mobile) and between different users (increased usability of metadata for both experts and non-experts). The ICT system is able to transmit information on different scales, providing users with up-to-date content; at the same time, administrators can constantly monitor its performance, being able to deduce useful information about the needs, habits and preferences of tourists [Clini et al. 2020].

The structure consists of three levels: an introductory first level that traces the fil rouge of the project, the Adriatic maritime identity network told by an ad hoc chosen testimonial; a second common level that collects and narrates the contents of the individual partners declined on the shared taxonomy, in order to allow a transversal reading of local uniqueness 
through mutual relations; and, finally, a third level, which refers to a vertical deepening on the individual local, physical or virtual Virtual Museums (fig. 4).

The Adrijo platform therefore allows the navigation of content through keywords and through a geographical navigation interface, particularly interesting if you want to access by activating the AR mode, when you are physically inside the port areas of the project partners. The cards and multimedia contents connected to them (galleries, audio, video, 3D models, tours and spherical images) are automatically placed in the surrounding space using the geo-referencing information of the mobile device you are using (fig. 5). The narrative exploits simple and well-considered digital communication practices and experiments with new ones, on which usability tests will be carried out, as soon as they will be put to system.

Fig. 5. Example of ARmode display of content that can be explored in the ADRIJO platform of the REMEMBER project. Simulation at Zadar port

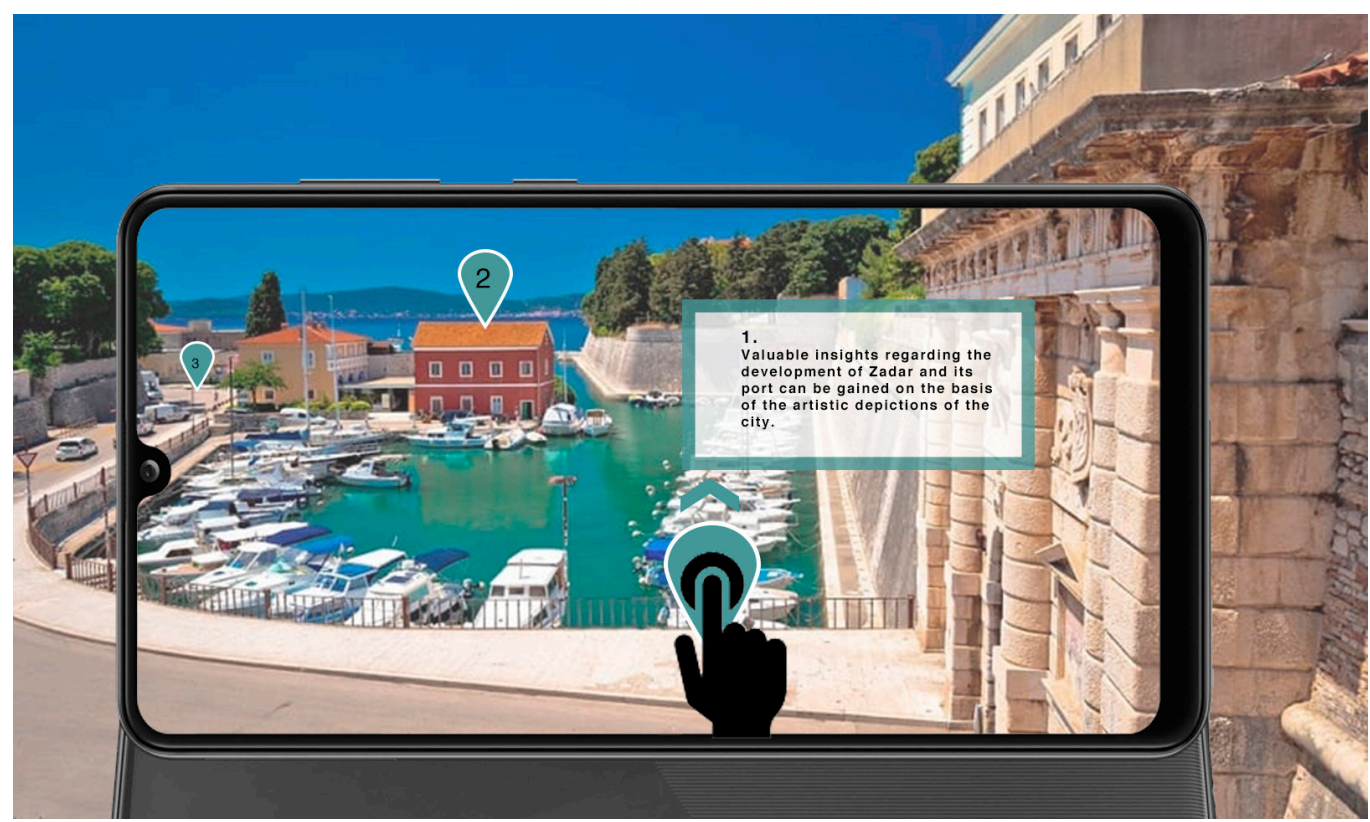

The Local Virtual Museum of the Ancona seaport

The proposed partnership and the technical experts involved, already active in many projects on Digital Cultural Heritage, have started a workflow able to develop high quality content and virtual experiences that refer to solid guidelines for virtual museums [Pescarin 20 I 4, pp. I3 I- |40]. The use of digital technologies plays an essential role in the creation of highly evocative and engaging products and installations, which allow visitors to learn about cultural heritage and sites through more stimulating experiences. However, the design of digital technologies requires a strategic vision that allows placing the technological element in a coherent plan of identity communication, starting from a clear identification of goals.

The virtual Museum of the Ancona seaport aims to accompany the tourists to discover the multiple aspects of the life of the seaport, exploiting the paradox of moving infrastructure: a reality of imposing, static structures, which nevertheless adapts to changing needs, technologies and traffic, moving with contemporaneity.

In fact, the port hosts advanced services, such as logistics, shipyards such as manufactures that combine artisan flair with the most advanced technology, traditional activities such as fishing, and passenger traffic - vocation of the port of Ancona and medium not only of people, but also of cultures, cultural contaminations and ideas. Another strand that intersects the story of the port is the awareness of the monumental and historical-artistic heritage 
of importance, testimonies left by over 2000 years of port activity on the same site in a constant overwriting.

On the integration between water and land, traditions and transformation, dialogue and comparison with the surrounding local community is the narration of the Ancona VM (fig. 6). To fulfill this mission, different languages will be used, also taking into account the international dimension of users and the need to convey easily assimilated messages: images, sounds and words contribute to the description of a network of points of interest -POI- usable by smartphones or other digital media to make this story immediately available between past and future.

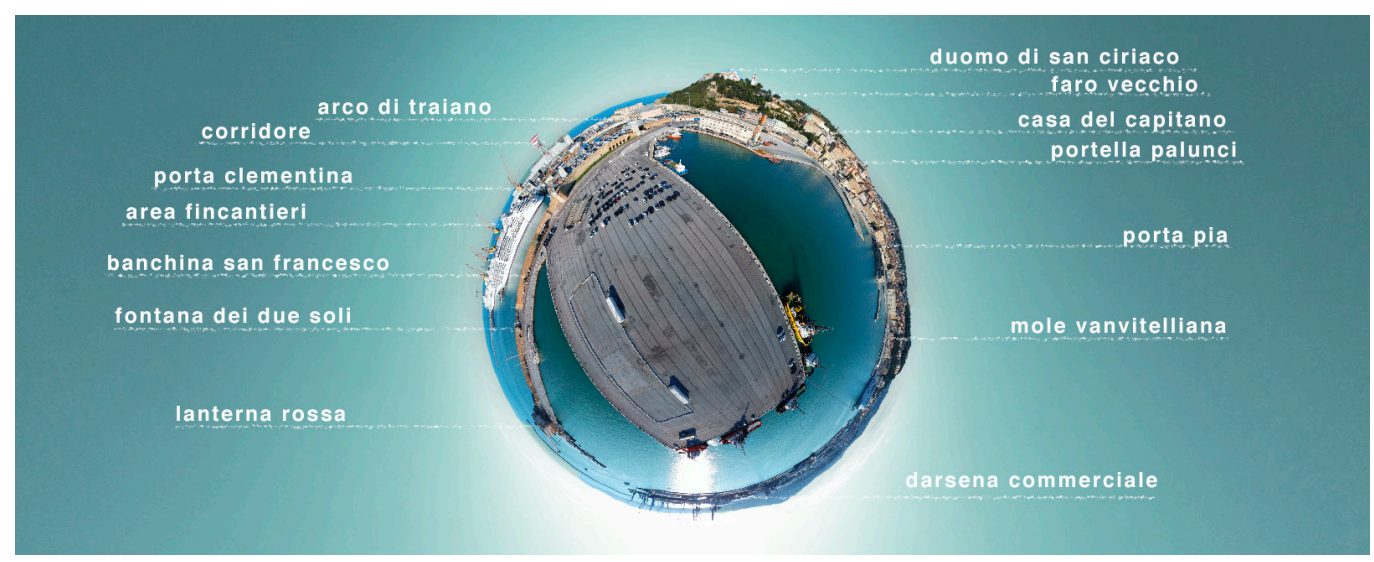

In particular, the path winds through $10 \mathrm{POI}$, located along $3 \mathrm{~km}$ of the port strip, a stretch full of places of life, among the most symbolic of this ecosystem: from the Red Lantern to the Mandracchio fish market (fig. 7).

In order to develop new forms of interaction, a hybrid form of viewing geo-located content has been designed, created ad hoc for some POI of the path, merging the AR Vision-based tracking already present in the ADRIJO common platform with an AR visualization on the real physical object. In the first place, as soon as the user frames the signage, identifying the

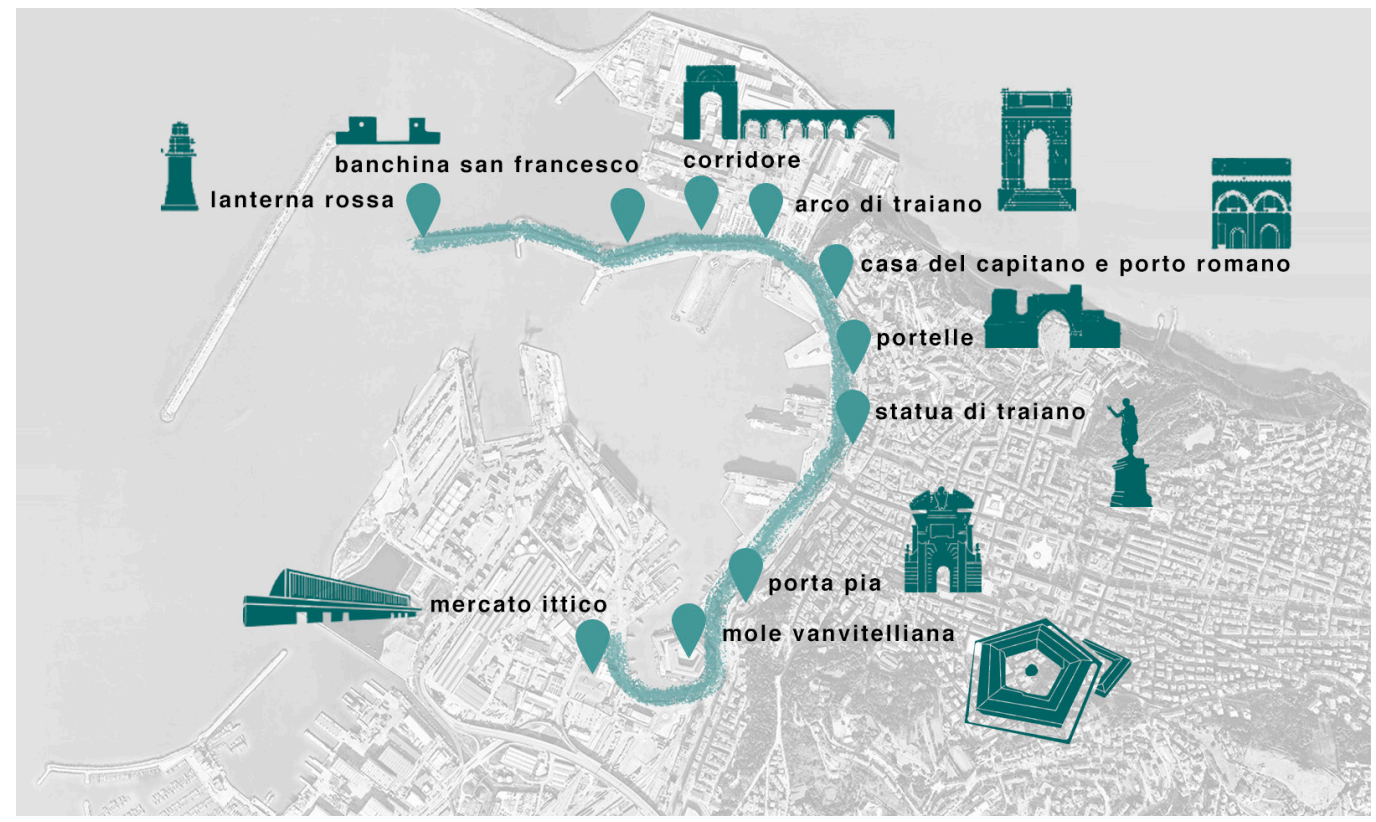


project and specially designed as Wayfinding, the automatic playback of a video introductory to the $\mathrm{POI}$ is activated. Then, the device tracks geo-referencing information, detecting and recognizing geometric features in the real environment to establish coordinate matches of 3D and 2D images. This part of the work is still under development and will be validated with usability tests.

Alongside the most exciting and vocative tales of images, sounds and videos of the real, you can explore virtual 3D digital content made according to a scientific approach of digital documentation. The numerous multi-temporal and multi-scale acquisition campaigns constitute a very large database from which the digital drawings of the most significant objects have been processed: in particular, the Clementine Gate and the Trajan's Arch are the most populated POI of tridimensional virtual content (figs. 8, 9). The methodology used integrates 3D survey tools and techniques, according to the standard procedures already established for digital documentation of $\mathrm{CH}$ (topography, laser scanner, drone photogrammetry and terrestrial photogrammetry).

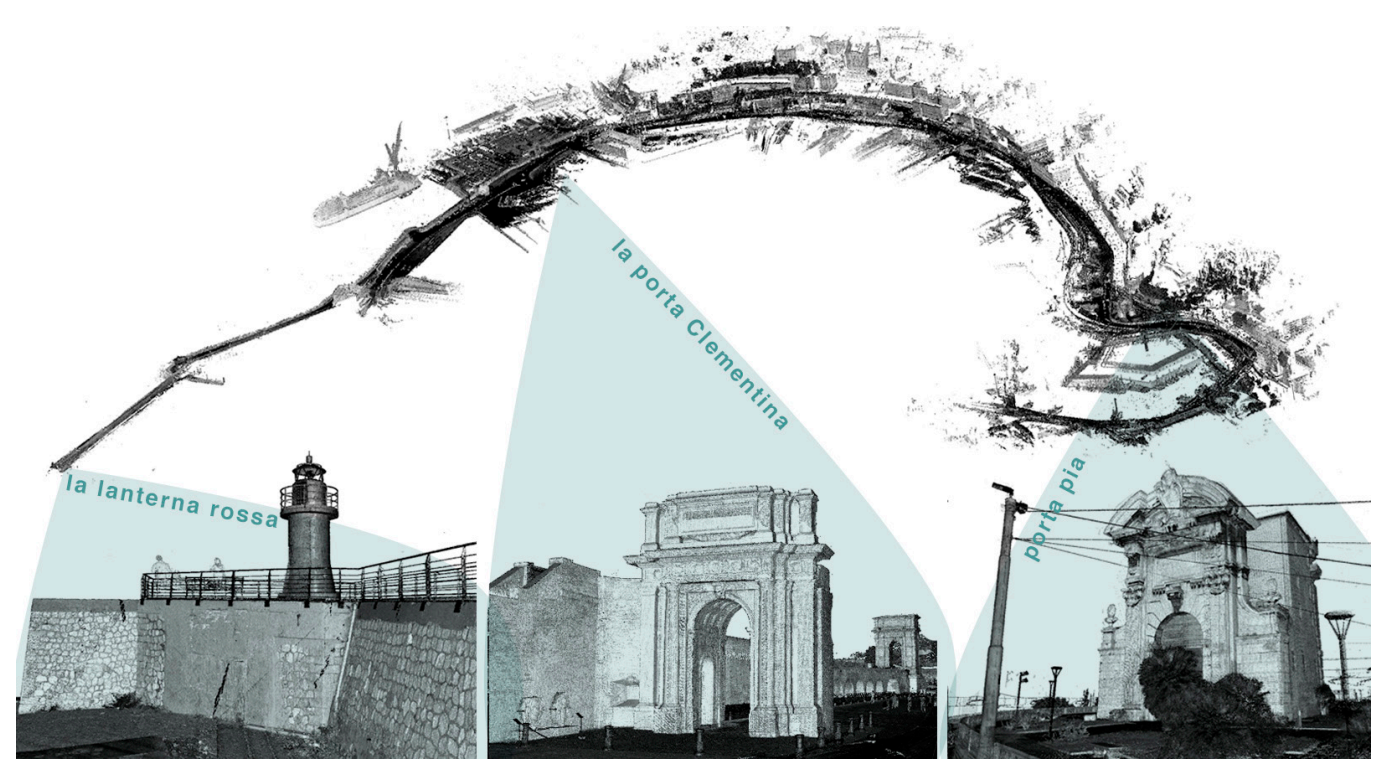

\section{Conclusions and future developments}

The pandemic has shown the fragility of our cultural heritage, but above all of our museum systems, often unarmed in the face of the emergency. The need for digital access to heritage has been firmly asserted and all operators of Digital Humanism must certainly work in this direction.

The REMEMBER project consciously operates in this way: the ADRIJO platform guarantees remote access to the maritime heritage of a network of 8 Italian and Croatian port-cities that affirm their cultural and social identity around the Adriatic Sea. One of the achievements is the democratization of access to our heritage in order to support diversity, inclusiveness, creativity and critical engagement in education and knowledge sharing.

In addition, it is mandatory to set up permanent networks in which public institutions cooperate and involve the private sector in the digitization of cultural material, in order to increase the online accessibility of Europe's cultural heritage and stimulate growth in European creative industries [European Union 20I8]. One of REMEMBER results is the cross-fertilization between different public institutions in order to allow the technology transfer in the domain of digital cultural heritage. The Port Authorities, in fact, act to enhance and promote 
Fig. 9. Three-dimensional in-depth study of Trajan's in-depth study of Trajan Arch, one of the POl of the LocalVirtual Museum cloud, mesh model, textured model, and grayscale orthoimage. port cultural elements, as well as to assurance the preservation of tangible and intangible maritime cultural heritage. The REMEMBER partnership is committed to stimulating innovation capacity, promoting the use of technology and digital skills and improving the role of cultural institutions in telling our European stories. To guarantee this objective, the project partnership, consisting for the most part of port authorities, joins the museum institutions and employs operators of digital cultural heritage, which through technology at the service of drawing and representation tailor-made new languages and new communication media. As in other cases, the access to the material and intangible assets of these places is confirmed to be the result of a process of development and cooperation that finds in the role of design the fulcrum of development and management.

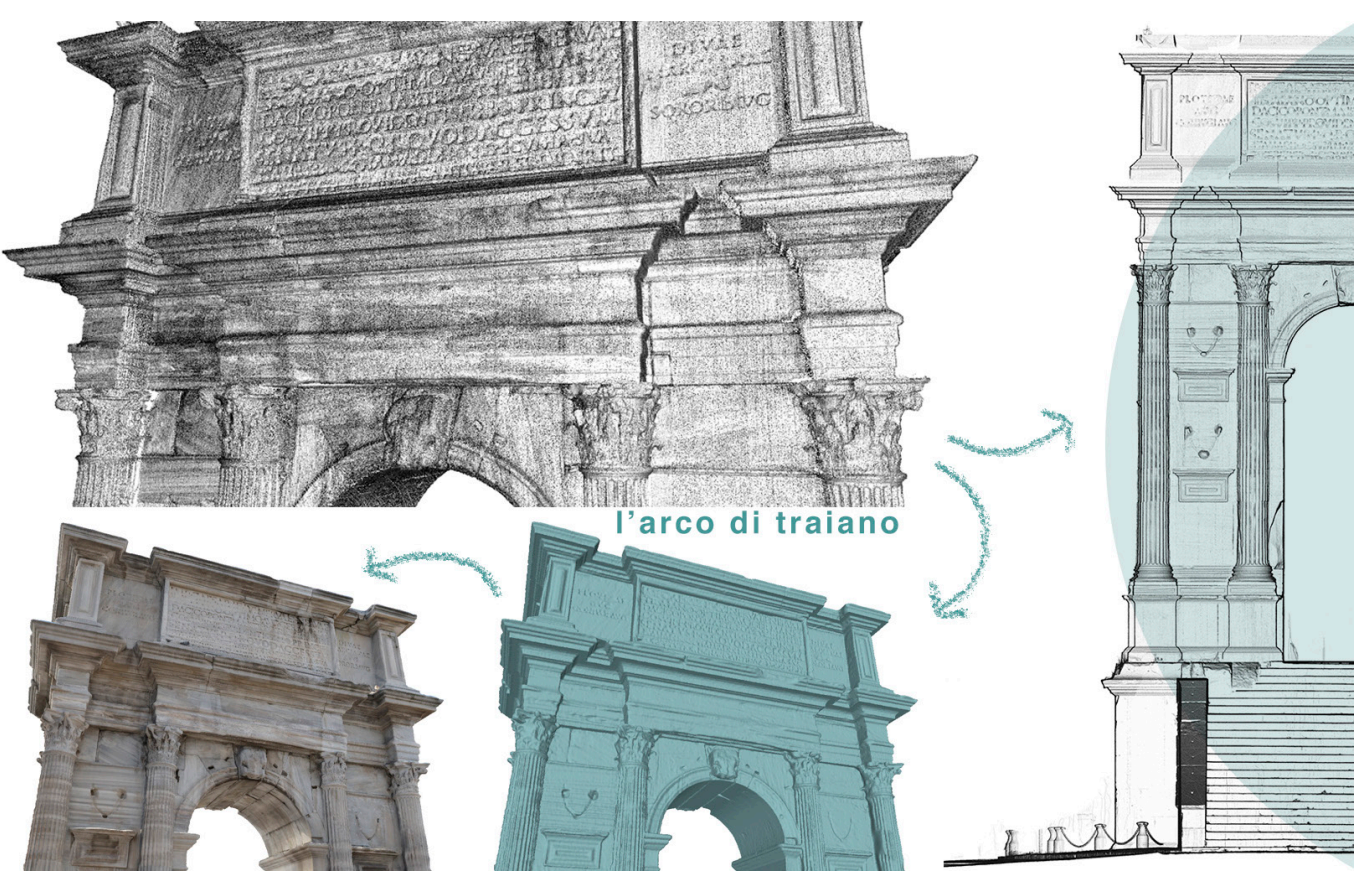

Acknowledgements

The project presented here is funded under the Interreg IT-HR 2019-202I programme, APPLICATION ID I004274I.The content of this document only reflects the author's point of view and the program authorities are not responsible for any use that may be made of the information contained therein. The authors thanks to Gianluca Gagliardini, Luigi Sagone and Floriano Capponi for their collaboration in the acquisition phases.

\section{References}

Anselmi S. (1996). Storie di Adriatico. Bologna: II Mulino.

Antinucci F. (2007). The virtual museum. In Archeologia e calcolatori. Supplement, pp. 79-86.

Cabanes P. (200I). Storie dell'Adriatico. Paris: Édition du Seuil.

Clini P. et al. (2017). Real/Not Real: Pseudo-Holography and Augmented Reality Applications for Cultural Heritage. In A. Ippoliti, M. Cigola (eds.). Handbook of Research on Emerging Technologies for Digital Preservation and Information Modeling. Chapter 9 Publisher: IGI Global, pp. 201-227.

Clini P. et al. (2020). ICT driven platform for high-quality virtual contents creation and sharing with e-Tourism purposes. The interreg IT-HR REMEMBER project. In CEUR Workshop Proceedings, vol. I, pp. 2687-269I.

Clini P., Quattrini R. (2020). Umanesimo digitale e bene comune? Linee guida e riflessioni per una salvezza possibile/Digital humanities and Commons: guidelines and recflections for a possible salvation. In Capitale Culturale. Studies on ( I I), pp. I 5 I - I75.

Djindjian F. (2007). The virtual museum: an introduction. In Archeologia e Calcolatori. Supplement, pp. 9- I4.

Empler T., Caldarone A., Fusinetti A. (2020). Musei tra narrazione, visualità e new media. In A. Arena et al. (a cura di). Connettere. Un disegno per annodare e tessere. $42^{\circ}$ Convegno internazionale dei Docenti delle Discipline della Rappresentazione. Milano: FrancoAngeli, pp. 3293-3312. 
European Commission (20II). COMMISSION RECOMMENDATION of 27 October $201 \mathrm{I}$ on the digitisation and online accessibility of cultural material and digital preservation (201 I/7I I/EU). In Official Journal of the European Union, pp. 39-43.

European Union (2018). Digital solutions in the field of cultural heritage. A Policy Brief from the Policy Learning Platform environment and resource efficiency.

Higginbottom G. (2020). Intangible Cultural Heritage. In Encyclopedia of Global Archaeology. Cham: Springer International Publishing, pp. 58||-58|4

ICOM (20I I). Museums and Sustainable Development: How can ICOM Support, in Concrete Terms, the Museum Communities Sustainable Development Projects?" In Proceedings of the Advisory Committee Meeting. Paris, France, 6-8 June 201 : <http:// archives.icom.museum/download/june20 I I/panels/I I0602_\%20JM_panel I.pdf> (accessed 202I, May 28).

Kirshenblatt-Gimblett B. (20 I 4). Intangible Heritage as Metacultural Production. In Museum International 66 (I -4), pp. I63- I 74 <https://www.tandfonline.com/doi/abs/I0.1 I I I/muse. I 2070> (accessed 2021, May 28).

Matvejević P. (1999). Mediterranean: A Cultural Landscape. Berkeley: University of California Press.

Mollica S., Marraffa A. (2020). La riconnessione delle città costiere. La rete dei fari italiani. In A. Arena (a cura di). Connettere. Un disegno per annodare e tessere. $42^{\circ}$ Convegno internazionale dei Docenti delle Discipline della Rappresentazione. Milano: FrancoAngeli, pp. 3553-3576.

Niccolucci F. (2007). Virtual museums and archaeology: an international perspective. In Archeologia e Calcolatori, Supplemento I, pp. 15-30.

Pescarin S. (2014). Museums and Virtual Museums in Europe: Reaching expectations. In SCIRES-IT-SClentific RESearch and Information Technology, 4 (I) pp. | 3 |- | 40.

Pugliese A. (20 I8). Musei, le esperienze digitali che conquistano il visitatore (e quelle che no). In Network Digital 360. <https:// www.agendadigitale.eu/cultura-digitale/musei-le-esperienze-digitali-che-conquistano-il-visitatore-e-quelle-che-no/> (accessed 2021, May 28).

Rodzi N.I.M., Zaki S.A., Subli S.M.H.S. (20I3). Between Tourism and Intangible Cultural Heritage. In Procedia - Social and Behavioral Sciences, vol. 85, pp. 4 II-420.

Salucci A., Petrillo D. (2020). Connessioni tra terra e cielo. Forma e immagine nel racconto delle qualità intangibili di uno spazio urbano. In A. Arena et al. (a cura di). Connettere. Un disegno per annodare e tessere. $42^{\circ}$ Convegno internazionale dei Docenti delle Discipline della Rappresentazione. Milano: FrancoAngeli, pp. 3774-3799.

Smith L., Akagawa N. (2008). Intangible Heritage. L. Smith \& N. Akagawa (eds.). London: Routledge.

UNESCO (2003). Convention for the safeguarding of the intangible cultural heritage.

Vecco M. (20I0). A definition of cultural heritage: From the tangible to the intangible. In Journal of Cultural Heritage, II (3), pp.32 I-324:<http://orcp.hustoj.com/wp-content/uploads/2016/01/20 I0-A-definition-of-cultural-heritage_From-the-tangible-to-the-intangible.pdf> (accessed 202I, May 28).

\section{Authors}

Paolo Clini, Università Politecnica delle Marche, p.clini@univpm.it

Ramona Quattrini, Università Politecnica delle Marche, rquattrini@univpm.it

Romina Nespeca, Università Politecnica delle Marche, r.nespeca@univpm.it

Renato Angeloni, Università Politecnica delle Marche, rangeloni@univpm.it

Mirco D'Alessio, Università Politecnica delle Marche, m.dalessio@pm.univpm.it

To cite this chapter. Clini Paolo, Quattrini Ramona, Nespeca Romina, Angeloni Renato, D'Alessio Mirco (202I). L'Adriatico come accesso alla cultura tangibile e intangibile dei porti: il Virtual Museum di Ancona/Adriatic Sea as an access to the tangible and intangible culture of ports: the Ancona Virtual Museum. In Arena A., Arena M., Mediati D., Raffa P. (a cura di). Connettere. Un disegno per annodare e tessere. Linguaggi Distanze Tecnologie. Atti del $42^{\circ}$ Convegno Internazionale dei Docenti delle Discipline della Rappresentazione/Connecting. Drawing for weaving relationship. Languages Distances Technologies. Proceedings of the $42^{\text {th }}$ International Conference of Representation Disciplines Teachers. Milano: FrancoAngeli, pp. $528-547$. 